\title{
Synthesis and Evaluation of the 2- Aminothiazoles as Anti-Tubercular Agents
}

\author{
Edward A. Kesicki ${ }^{1}$, Mai A. Bailey ${ }^{1}$, Yulia Ovechkina ${ }^{1}$, Julie V. Early ${ }^{1}$, Torey Alling ${ }^{1}$, \\ Julie Bowman ${ }^{1}$, Edison S. Zuniga', Suryakanta Dalai ${ }^{2}$, Naresh Kumar', \\ Thierry Masquelin ${ }^{3}$, Philip A. Hipskind ${ }^{3}$, Joshua O. Odingo ${ }^{1}$, Tanya Parish $^{1 *}$
}

1 TB Discovery Research, Infectious Disease Research Institute, Seattle, Washington, United States of America, 2 Jubilant Chemsys Limited, B-34, Sector 58, Noida, India, 3 Lilly Research Laboratories, Eli Lilly and Company, Indianapolis, Indiana, United States of America

* tanya.parish@idri.org

\section{Abstract}

The 2-aminothiazole series has anti-bacterial activity against the important global pathogen Mycobacterium tuberculosis. We explored the nature of the activity by designing and synthesizing a large number of analogs and testing these for activity against $M$. tuberculosis,

Citation: Kesicki EA, Bailey MA, Ovechkina Y, Early JV, Alling T, Bowman J, et al. (2016) Synthesis and Evaluation of the 2-Aminothiazoles as AntiTubercular Agents. PLoS ONE 11(5): e0155209. doi:10.1371/journal.pone.0155209

Editor: Mohamed N. Seleem, Purdue University, UNITED STATES

Received: March 28, 2016

Accepted: April 26, 2016

Published: May 12, 2016

Copyright: ๑ 2016 Kesicki et al. This is an open access article distributed under the terms of the Creative Commons Attribution License, which permits unrestricted use, distribution, and reproduction in any medium, provided the original author and source are credited.

Data Availability Statement: All relevant data are within the paper.

Funding: This research was funded in part by Eli Lilly and Company in support of the mission of the Lilly TB Drug Discovery Initiative and in part by grant OPP1024038 from the Bill \& Melinda Gates Foundation. Funding for the Lilly TB Drug Discovery Initiative was provided by Eli Lilly and Company. The following authors are employed by Eli Lilly and Company: TM and PAH. Eli Lilly and Company provided support in the form of salaries for authors TM and PAH, but did not have any additional role in the study design, data collection and analysis, as well as eukaryotic cells. We determined that the $\mathrm{C}-2$ position of the thiazole can accommodate a range of lipophilic substitutions, while both the $\mathrm{C}-4$ position and the thiazole core are sensitive to change. The series has good activity against $M$. tuberculosis growth with sub-micromolar minimum inhibitory concentrations being achieved. A representative analog was selective for mycobacterial species over other bacteria and was rapidly bactericidal against replicating M. tuberculosis. The mode of action does not appear to involve iron chelation. We conclude that this series has potential for further development as novel antitubercular agents.

\section{Introduction}

Tuberculosis (TB) remains a deadly global threat and continues to be one of the leading causes of death worldwide [1]. Although significant strides have been made toward combating this disease, coordinated global health efforts have fallen short, in part due to patient incompliance to current treatment regimens [1]. The current minimum treatment regimen for $\mathrm{TB}$ requires a combination therapy of isoniazid (INH), rifampicin (RIF), pyrazinamide (PZA), and ethambutol (EMB) for two months, followed by INH and RIF for an additional four months [2]. This intensive therapy is becoming increasingly ineffective with the emergence of both multidrugresistant TB (MDR-TB) and extensively drug-resistant TB (XDR-TB). MDR-TB is resistant to isoniazid and rifampicin, whereas $\mathrm{XDR}-\mathrm{TB}$ is resistant to isoniazid, rifampicin, one of the fluoroquinolones, as well as one injectable drug. Both MDR-TB and XDR-TB have the potential to render our current treatment regimen ineffective. Therefore, the discovery and development of novel TB drugs is urgent.

Researchers have relied on a variety of screening techniques to identify promising compound series for TB drug development. A large number of compound series have been 
decision to publish, or preparation of the manuscript. The specific roles of these authors are articulated in the 'author contributions' section. The following authors are employed by Jubilant Chemsys Limited: SD and NK. Jubilant Chemsys Limited provided support in the form of salaries for authors SD and NK, but did not have any additional role in the study design, data collection and analysis, decision to publish, or preparation of the manuscript. The specific roles of these authors are articulated in the 'author contributions' section.

Competing Interests: This work was funded by the Lilly TB Drug Discovery Initiative (http://www. tbdrugdiscovery.org/) and funding was provided by Eli Lilly and Company. The following authors are employed by Eli Lilly \& Company: TM and PAH. The following authors are employed by Jubilant Chemsys Limited: SD and NK. There are no patents, products in development or marketed products to declare. This does not alter the authors' adherence to all the PLOS ONE policies on sharing data and materials.

Abbreviations: AT, aminothiazole; MIC, minimum inhibitory concentration; TC50, half-maximum inhibitory concentration; MBC, minimum bactericidal concentration; SI, selectivity index. identified via high-throughput phenotypic screening assays [3-5]. Among the compound classes identified from such phenotypic screens, the aminothiazole (AT) series is promising for its activity [5]. The AT core is a common motif currently found in several FDA-approved drugs, such as the nonsteroidal anti-inflammatory drug meloxicam [6], the tyrosine kinase inhibitor dasatinib [7], and cefdinir, a 3rd-generation cephalosporin [8,9]. Most recently, AT derivatives with activity against $M$. tuberculosis were described [10].

One of the key features of the AT motif is its versatility to accommodate a large number of different functional groups without significant loss of activity [10,11]. In addition, the ease with which AT analogs can be synthesized is an attractive quality, as it lends itself to the rapid exploration of structure-activity relationship (SAR) studies. Furthermore, AT analogs can be achieved in a few steps from inexpensive, commercially available starting materials, which may be well suited for large scale production. We focused our efforts on a full evaluation of this series to identify compounds with good activity against $M$. tuberculosis and good selectivity over mammalian cells.

\section{Results \& Discussion \\ Chemistry}

We initiated our SAR investigations by synthesis of reference compound $\mathbf{1}$, which was selected based on the literature report of good activity against M. tuberculosis (MIC $<0.1 \mu \mathrm{M})$ [5]. We confirmed the activity, albeit with a shift in our assay (MIC $=8 \mu \mathrm{M})$.

Beginning with $\mathbf{1}$ as a confirmed active compound, we designed and synthesized analogs to explore the chemical space, and establish the structural and functional requirement for activity against M. tuberculosis. We explored three main segments to the series, as depicted in Fig 1, namely the substitutions at the C-2 (III) and C-4 (I) positions as well as various replacements for the thiazole core (II).

We synthesized and evaluated a series of AT for SAR determination and identified a number of analogs that possess excellent activity against $M$. tuberculosis. The synthesis of AT is straightforward and is depicted in Fig 2.

Aminothiazoles 16-29 were achieved via a condensation reaction between a suitably substituted thiourea (2) and a substituted bromoketone (3) in a Hantzsch reaction [10,12-14]. Where necessary, the thiourea (2) was prepared by a reaction between a corresponding amine with benzoyl isothiocyanate followed by base hydrolysis of the resulting $N$-benzoylthiourea to

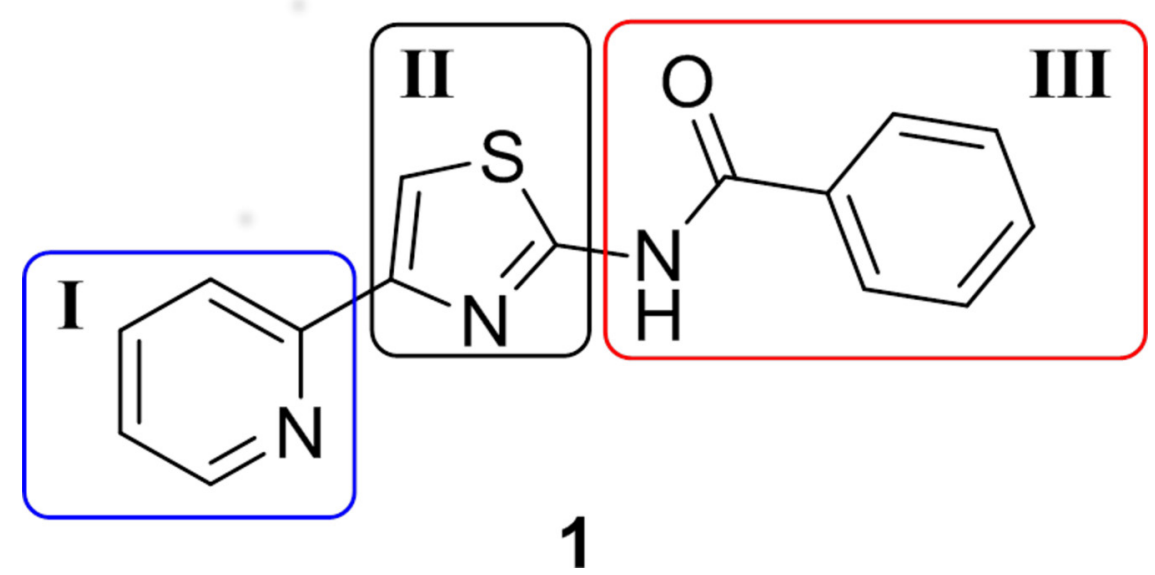

Fig 1. Reference compound 1. Three core segments illustrated with box and numbering.

doi:10.1371/journal.pone.0155209.g001 

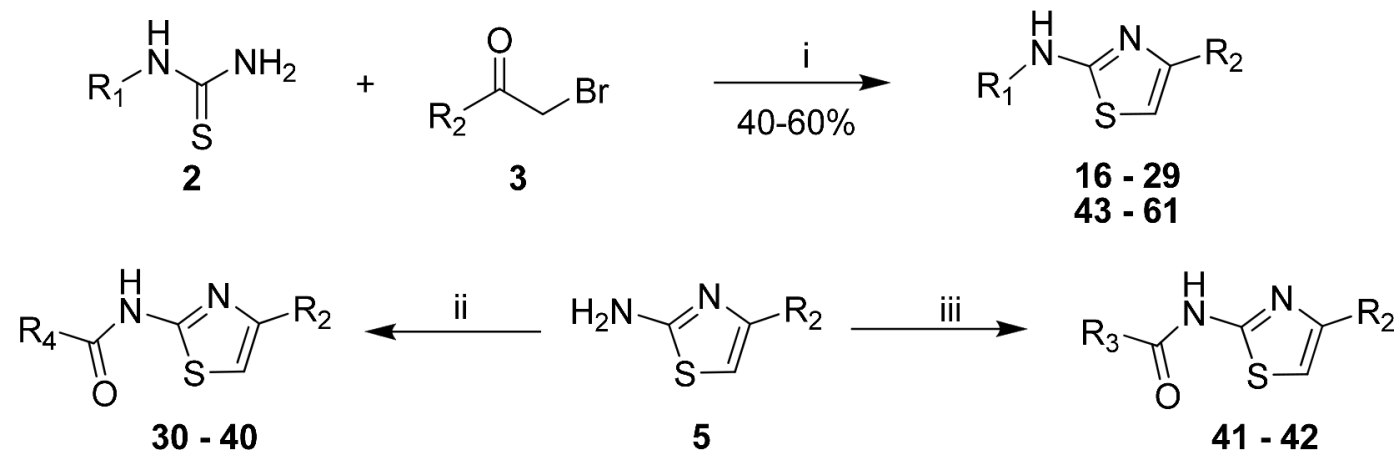

Fig 2. Chemical synthesis of 2-aminothiazole analogs. Reagents: (i) $\mathrm{EtOH}, 70^{\circ} \mathrm{C}, 2 \mathrm{~h}$; (ii) $\mathrm{R}_{4} \mathrm{COX}, \mathrm{Et}_{3} \mathrm{~N}, \mathrm{THF}, \mathrm{r}$. t., $1 \mathrm{~h}$; (iii) $\mathrm{R}_{3} \mathrm{NCO}, \mathrm{Et}_{3} \mathrm{~N}$, THF, r.t., $1 \mathrm{~h}$.

doi:10.1371/journal.pone.0155209.g002

give 2. The amine intermediate (5) prepared in this manner was subsequently acylated to give 30-40 or treated with cyclopentyl isocyanate or phenyl isocyanate to give urea 41 or 42, respectively. Analogs 43-61, which examine different substituents at the C-2 position of the thiazole core, were prepared in a similar manner.

The C-4 ketone (62) and carboxamide (63) were prepared from carboxylic acid 6, which is accessible from commercially available ethyl 2-aminothiazole-4-carboxylate (Fig 3). Treatment of compound 6 with 2-chloropyridine in THF under reflux conditions followed by conversion to Weinreb amide and Grignard in the presence of methyl magnesium bromide gave $\mathbf{6 2}$ in $49 \%$ yield. Similarly, acylation of $\mathbf{6}$ gave intermediate 7 , which after a similar Weinreb amide conversion afforded 63.

We also prepared analogs which are comprised of modifications to the thiazole core. Thiadiazole 64 was prepared from commercial 2-aminothiadiazole (7) via standard amidation chemistry. Thiadiazole 65 and oxadiazole 66 were prepared in two steps (Fig 4). Treating hydrazide $\mathbf{8}$ with isothiocyanate and /or isocyanate $\mathbf{9}$ gave intermediate 10, which after acidcatalyzed ring-closure afforded thiadiazole 65. Treatment of 10 with EDC gave oxadiazole 66.

The pyrimidine-based analog $\mathbf{6 7}$ was prepared according to Fig 5. Amination of dihalide 11 in the presence of 2,6-dimethylaniline gave intermediate 12. Alkylation of $\mathbf{1 2}$ in the presence of 2-(tributylstannyl)pyridine under Stille coupling conditions in Fig 5 afforded 67.

The synthesis of pyrazole analogs 69 and 70 is shown in Fig 6.2-Hydrazinopyridine (13) was reacted with methoxyacrylonitrile (14) in the presence of base to give pyridylpyrazole intermediate 15 , which was readily converted to 69 via standard acylation protocols. Treatment of 15 with isocyanate afforded urea $\mathbf{7 0 .}$<smiles>O=C(O)c1csc(-c2ccccn2)n1</smiles>

$6 \mathrm{a}$

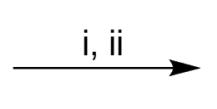<smiles>CC(=O)c1csc(-c2ccccn2)n1</smiles>

62

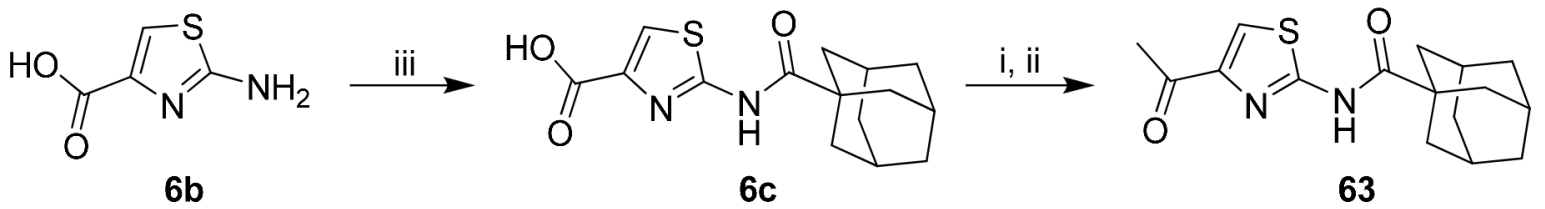

Fig 3. Chemical synthesis of $\mathrm{C}-4$ ketone and carboxamide analogs. Reagents: (i) $\mathrm{EDC} . \mathrm{HCl}, \mathrm{HOBt}, \mathrm{NCH}_{3}\left(\mathrm{OCH}_{3}\right)$, DIPEA, $\mathrm{CH}_{2} \mathrm{Cl}_{2}, 16$ h; (ii) $\mathrm{CH}_{3} \mathrm{MgBr}$, THF, $-78^{\circ} \mathrm{C}$-r.t., $2 \mathrm{~h}$; (iii) 1-adamantanoyl chloride, $\mathrm{Et}{ }_{3} \mathrm{~N}$, THF, r.t., 1 h.

doi:10.1371/journal.pone.0155209.g003 
<smiles>Nc1nnc(-c2ccccn2)s1</smiles>

7<smiles>NNC(=O)c1ccccn1</smiles>

8

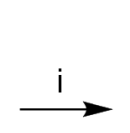<smiles>CC(C)(C)c1ccc(C(=O)Nc2nnc(-c3ccccn3)s2)cc1</smiles>

64<smiles>[X]C(NNC(=O)c1ccccn1)Nc1c(C)cccc1C</smiles>

10

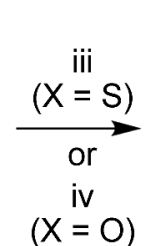

$(X=O)$<smiles>[X]c1nnc(-c2ccccn2)[X]1Nc1c(C)cccc1C</smiles>

$65(X=S)$ $66(X=0)$

Fig 4. Chemical synthesis of analogs comprised of thiazole core replacement. Reagents:: (i) 4-(t-butyl)PhCOCl, $\mathrm{EtOH}, 1 \mathrm{~h}$; (ii) $\mathrm{EtOH}$, reflux, 16 h; (iii) $\mathrm{H}_{2} \mathrm{SO}_{4}$, r.t., 16 h; (iv) $\mathrm{EDC}, \mathrm{CH}_{2} \mathrm{Cl}_{2}$, r.t., 16 h.

doi:10.1371/journal.pone.0155209.g004

\section{Structure-Activity Relationship (SAR) studies}

The goal of our research efforts was to explore the AT compound class, and establish SAR with respect to activity against $M$. tuberculosis and selectivity over mammalian cells. Compounds were designed to explore various segments of the hit structure 1 including the thiazole core. The 2-pyridyl was previously reported to be a preferred residue at the C-4 position [5]. Therefore, beginning with a 2-pyridyl substituent fixed at C-4 position of the thiazole, we explored the C-2 position for optimal substitution pattern (Fig 7).

We synthesized analogs with various substitutions at the C-2 of the thiazole, including a diversity of amines (16-29), amides (30-40) and ureas (41 and 42). The un-substituted amine (16) and the aliphatic cyclohexylamine (27) were less active. Heteroaromatic amines such as 20 had the best activity but were also cytotoxic. The isosteric 3- and 4-pyridyl analogs 22 and $\mathbf{2 4}$ showed no activity indicating a preference for the 2 -isomer. Aniline $\mathbf{2 1}$ had moderate activity comparable to the more lipophilic analog 26.

We noted increased anti-tubercular activity in compounds with amide or urea substituents at C-2 position, as compared to amines. For example, the cyclohexylamide 35 had 14-fold greater activity as compared to the analogous amine 27 , and the amide 33 had 3 -fold greater activity over the analogous amine 26. Both 33 and 35 had good separation from cytotoxicity, with respective selectivity index $\left(\mathrm{SI}=\mathrm{MIC} / \mathrm{TC}_{50}\right)$ of 37 and 28 . The potency and selectivity of these compounds highlighted the benefit of incorporating an amide linkage to the core, thus providing a good starting point for compound optimization.

Urea analogs were also more active relative to their aniline counterparts; for example the cyclopentyl urea analog 41 demonstrated good activity against $M$. tuberculosis, as well as selectivity (SI = 26). A phenyl urea analog 42 had 3-fold higher activity as compared to the aniline 21. Furthermore, lipophilic amides retained activity, while attempts to introduce small alkyl (31, and 32) or small polar (34, 36 and 37) amides generally resulted in loss of activity.<smiles>CC(C)C</smiles>

11<smiles>Cc1cccc(C)c1Nc1cc(Cl)ncn1</smiles>

12<smiles>Cc1cccc(C)c1Nc1cc(-c2ccccn2)ncn1</smiles>

67

Fig 5. Chemical synthesis of pyrimidine-based analogs. Reagents: (i) 2,6-dimethylaniline, THF, reflux, $16 \mathrm{~h}$; (ii) 2-(tributylstannyl)pyridine, $\mathrm{Pd}\left(\mathrm{PPh}_{3}\right), \mathrm{DMF}, 100^{\circ} \mathrm{C}, 16 \mathrm{~h}$.

doi:10.1371/journal.pone.0155209.g005 


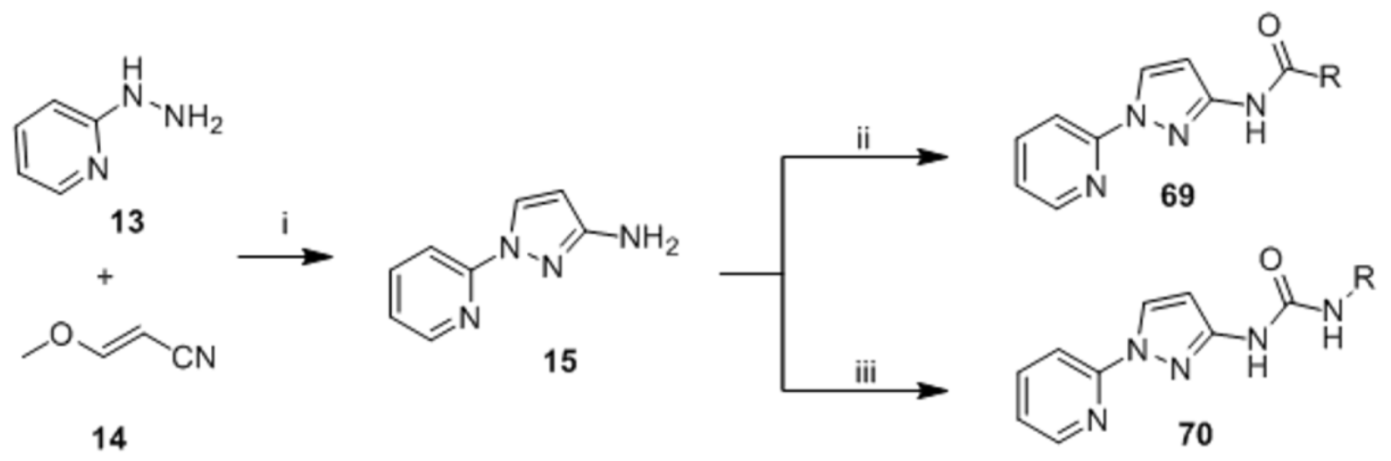

Fig 6. Chemical synthesis of pyrazole-based analogs. Reagents: (i) $\mathrm{KO}{ }^{t} \mathrm{Bu}, \mathrm{BuOH}$, reflux, $3 \mathrm{~h}$; (ii) $\mathrm{RCOCl}$, THF, r.t., $1 \mathrm{~h}$; (iii) RNCO, THF, $1 \mathrm{~h}$.

doi:10.1371/journal.pone.0155209.g006

Consistent with prior reports, we found that the placement of a 2-pyridyl unit at C-4 position of the thiazole core conferred good activity [10,11]. Given the limited scope of these reports on C-4 SAR, we decided to further explore requirements for activity at this position. We designed, synthesized and evaluated a diversity of substituents ranging in structural and functional scope to include alkyls, aromatics, heteroaromatics and specific 2-pyridyl surrogates (Fig 8).<smiles>[R]Nc1nc(-c2ccccn2)cs1</smiles>

$16-29$<smiles>[R]C(=O)Nc1nc(-c2ccccn2)cs1</smiles>

$30-42$

\begin{tabular}{|c|c|c|c|c|c|c|c|c|c|}
\hline Cpd & $\mathbf{R}_{1}$ & MIC $^{\mathrm{a}}$ & $\mathrm{TC}_{50}{ }^{\mathrm{b}}$ & SI & Cpd & $\mathbf{R}_{1}$ & $\mathrm{MIC}^{\mathrm{a}}$ & $\mathrm{TC}_{50}{ }^{\mathrm{b}}$ & SI \\
\hline Rif & - & 0.004 & $>100$ & ND & & & & & \\
\hline 16 & $\mathrm{H}$ & $>20$ & $>100$ & ND & 30 & $t$-butyl & 2.8 & 32 & 11 \\
\hline 17 & 2,6-(di-F)phenyl & 2.1 & 4.0 & 1.9 & 31 & $\mathrm{Me}$ & $>20$ & $>100$ & ND \\
\hline 18 & 2-( $\left(\mathrm{CF}_{3}\right)$ phenyl & 11 & 30 & 2.7 & 32 & cyclopropyl & $>20$ & $>100$ & ND \\
\hline 19 & 2,6-(di-Me)phenyl & 4.5 & 7.0 & 1.6 & 33 & 4-(t-Bu)phenyl & 0.7 & 26 & 37 \\
\hline 20 & 2-pyridyl & 0.8 & 0.20 & 0.3 & 34 & $\mathrm{Me}_{2} \mathrm{NCH}_{2^{-}}$ & $>20$ & 54 & ND \\
\hline 21 & phenyl & 3.7 & 16 & 4.3 & 35 & cyclohexyl & 1.4 & 39 & 28 \\
\hline 22 & 3-pyridyl & $>20$ & $>100$ & ND & 36 & $\mathrm{AcOCH}_{2-}$ & $>20$ & $>100$ & ND \\
\hline 23 & 2-(MeO)phenyl & 20 & 17 & 0.9 & 37 & $\mathrm{HOCH}_{2-}$ & $>20$ & $>100$ & ND \\
\hline 24 & 4-pyridyl & $>20$ & $>100$ & ND & 38 & 4-( $\left(\mathrm{NO}_{2}\right)$ phenyl & 1.2 & 3.0 & 2.5 \\
\hline 25 & 1-naphthyl & 6.4 & 6.0 & 0.9 & 39 & 2-(OH)phenyl & 1.4 & 11 & 7.9 \\
\hline 26 & 4-(t-Bu)phenyl & 2.4 & $\mathrm{ND}$ & ND & 40 & 3,5-(di-NO $\left.{ }_{2}\right)$ phenyl & $>20$ & 54 & ND \\
\hline 27 & cyclohexyl & 20 & 6.0 & 0.3 & 41 & cyclopentyl-NH- & 1.6 & 41 & 26 \\
\hline 28 & 4- $\left(\mathrm{CF}_{3}\right)$ phenyl & 20 & 5.0 & 0.3 & 42 & phenyl-NH- & 1.2 & $\mathrm{ND}$ & ND \\
\hline 29 & 2-naphthyl & 2.9 & 9.0 & 3.1 & & & & & \\
\hline
\end{tabular}

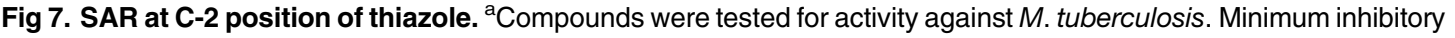
concentration (MIC, in $\mu \mathrm{M}$ ) is the minimum concentration required to inhibit the growth of $M$. tuberculosis in liquid culture. MICs of active compounds are the average of two independent experiments. $\left.{ }^{\text {b } T o x i c ~ c o n c e n t r a t i o n ~(T C 50, ~ i n ~} \mu \mathrm{M}\right)$ is the concentration required to inhibit growth of Vero cells by $50 \%$. Selectivity index (SI) is the ratio of TC50 to MIC. Cpd = compound; Rif = rifampicin; ND = not determined.

doi:10.1371/journal.pone.0155209.g007 
<smiles>[R]Nc1nc([R2])cs1</smiles>

$43-63$

\begin{tabular}{|c|c|c|c|c|c|c|c|c|c|c|c|}
\hline Cpd & $\mathbf{R}_{1}$ & $\mathbf{R}_{\mathbf{2}}$ & MIC $^{\mathrm{a}}$ & $\mathrm{TC}_{50}^{\mathrm{b}}$ & SI & Cpd & $\mathbf{R}_{\mathbf{1}}$ & $\mathbf{R}_{2}$ & MIC $^{\mathrm{a}}$ & $\mathrm{TC}_{50} \mathrm{~b}$ & SI \\
\hline 43 & & phenyl & $>20$ & 14 & ND & 55 & & phenyl & $>20$ & 90 & ND \\
\hline 44 & & 2-thiophenyl & $>20$ & 13 & ND & 56 & & 2-thiophenyl & $>20$ & 48 & ND \\
\hline 45 & & 2-naphthyl & $>20$ & 56 & ND & 57 & & 2-thiazolyl & 20 & 31 & 1.6 \\
\hline 46 & & 2-(MeO)phenyl & $>20$ & 54 & ND & 58 & & 2-pyrazinyl & 14 & $>50$ & ND \\
\hline 47 & & 2-(OH)phenyl & $>20$ & 20 & ND & 59 & & 3-pyrazolyl & 20 & 40 & 2.0 \\
\hline \multirow[t]{2}{*}{48} & & 5-adamantyl & $>20$ & 39 & ND & 60 & & 2-quinolyl & 1.5 & 6.0 & 4.0 \\
\hline & & & & & & 61 & & $\begin{array}{l}\text { 4- } \\
\text { pyrimidinyl }\end{array}$ & 15 & 37 & 2.5 \\
\hline 49 & & phenyl & $>20$ & $>100$ & ND & 62 & & $\mathrm{MeC}(=\mathrm{O})-$ & $>20$ & $>100$ & ND \\
\hline 50 & & 2-thiophenyl & $>20$ & $>100$ & ND & & & & & & \\
\hline 51 & & 3-pyridyl & $>20$ & 94 & ND & & & & & & \\
\hline 52 & & 2-pyrazinyl & 20 & $>100$ & ND & 63 & & $\operatorname{MeC}(=0)-$ & $>20$ & 82 & ND \\
\hline 53 & & 4-pyrimidinyl & 20 & 51 & 2.6 & & & & & & \\
\hline 54 & & 3-pyrazolyl & $>20$ & 44 & ND & Rif & - & - & 0.004 & $>100$ & ND \\
\hline
\end{tabular}

Fig 8. SAR at C-4 position of thiazole core. ${ }^{\mathrm{a}} \mathrm{MIC}(\mu \mathrm{M})$ is the minimum concentration required to inhibit the growth of $M$. tuberculosis in liquid culture. MICs of active compounds are the average of two independent experiments. ${ }^{b}$ Toxic concentration $\left(\mathrm{TC}_{50}\right.$, in $\left.\mu \mathrm{M}\right)$ is the concentration required to inhibit growth of Vero cells by $50 \%$. Selectivity index $(\mathrm{SI})$ is the ratio of $\mathrm{TC}_{50}$ to $\mathrm{MIC}$. Cpd $=$ compound; Rif = rifampicin; ND = not determined.

doi:10.1371/journal.pone.0155209.g008

These analogs were designed as combinations with selected C-2 residues known to confer good activity. The 3-pyridyl (51) isomer was devoid of any activity, an indication of a specific preference for the 2-pyridyl residue at C-4 position. In general, C-4 alkyls, such as $\mathbf{4 8}$, or plain aromatics $(43,45,49$ and 55$)$ were inactive. 2-Pyridyl replacements with 2-methoxyphenyl (46) or 2-hydroxyphenyl (47) yielded analogs devoid of any activity. Several other 2-pyridyl isosteric replacements tested showed no activity. The C-4 carboxamide or ketone (62 and 63) analogs also tested inactive. 2-Pyrazinyl $(\mathbf{5 2}, \mathbf{5 8}), 4$-pyrimidinyl $(\mathbf{5 3}, \mathbf{6 1})$ and 2-quinolyl $(\mathbf{6 0})$ analogs showed moderate activity. However, these compounds also showed moderate cytotoxicity. Accommodation of these residues at C- 4 however provides an opportunity for modulating physicochemical properties of the compound series without much penalty in activity.

We further synthesized thiazole core replacements (Fig 9). We selected optimal pairs of C2/C-4 substitution patterns established from our SAR studies of the thiazole scaffold to investigate alternative scaffolds. Thus, 2,6-dimethylanilino, 4-tert-butylbenzamido, adamantylcarboxamido and 1-cyclopentylurea units were selected as optimized C-2 residues for pairing with 2-pyridyl unit at C-4 (Fig 9).

We investigated isosteric replacement of the thiazole scaffold in amine $19(\mathrm{MIC}=4.5 \mu \mathrm{M})$ compared to thiadiazole 65 , oxadiazole 66 , and pyrimidine 67 . In addition, we investigated thiazole replacement of $33(\mathrm{MIC}=0.70 \mu \mathrm{M})$ by comparing the activity against $M$. tuberculosis of related thiadiazole 64 and pyrimidine 68 . We also looked into replacing the thiazole with a pyrazole (69 and 70). However, all modifications resulted in total loss of activity. These findings demonstrate that isosteric replacement of the thiazole core by other five- or six-membered heterocyclics do not necessarily produce compounds with retained biological activity i.e. they are 


Cpd

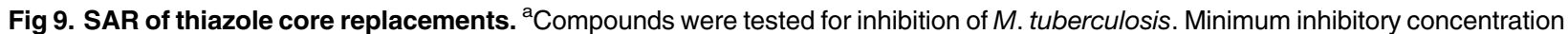
(MIC, in $\mu \mathrm{M}$ ) is the minimum concentration required to completely inhibit the growth of $M$. tuberculosis in liquid culture. MICs of active compounds are the average of two independent experiments. ${ }^{\mathrm{b}}$ Toxic concentration $\left(\mathrm{TC}_{50}\right.$, in $\left.\mu \mathrm{M}\right)$ is the concentration required to inhibit growth of Vero cells by $50 \%$. Selectivity index (SI) is the ratio of TC50 to MIC. Cpd = compound; Rif = rifampicin; ND = not determined.

doi:10.1371/journal.pone.0155209.g009

not bioisosteres. Therefore, we conclude that the thiazole core must play a significant role in the activity against $M$. tuberculosis, in addition to the structural display of key residues.

\section{Aminothiazoles have limited broad spectrum activity}

Two compounds were selected for testing against other bacterial species-we used the nonpathogenic mycobacterial species Mycobacterium smegmatis, as well as Staphylococcus aureus (Gram positive) and Escherichia coli (Gram negative) (Table 1). Both compounds were potent against $M$. tuberculosis, but also had activity against $M$. smegmatis, suggesting that the series targets mycobacteria broadly. One compound also had activity against $S$. aureus, suggesting that there may be limited broad spectrum activity, but neither compound was active against $E$. coli.

\section{Aminothiazoles have bactericidal activity against $M$. tuberculosis}

We determined the effectiveness of a representative compound in killing aerobically-growing M. tuberculosis. Compound $\mathbf{2 0}$ had rapid killing activity, resulting in complete sterilization of cultures ( $>4 \log$ kill) within 7 days (Fig 10), even at $0.625 \mu \mathrm{M}$. The minimum bactericidal concentration (MBC), defined as $3 \log$ kill in 21 days, was less than the MIC i.e. $<0.5 \mu \mathrm{M}$, confirming that this compound is bactericidal (defined as $\mathrm{MBC} / \mathrm{MIC}$ ratio $<4$ ).

Table 1. Spectrum of activity against bacterial species. The MIC against four bacterial species was determined on solid medium using the agar serial proportion method. $\mathrm{MIC}_{99}$ is the minimum concentration required to prevent growth $99 \%$ of bacteria.

\begin{tabular}{|c|c|c|c|c|}
\hline Compound & $\begin{array}{l}\text { Mycobacterium tuberculosis } \\
\text { MIC }_{99}(\mu \mathrm{M})\end{array}$ & $\begin{array}{l}\text { Mycobacterium smegmatis } \mathrm{MIC}_{99} \\
(\mu \mathrm{M})\end{array}$ & $\begin{array}{l}\text { Escherichia coli } \mathrm{MIC}_{99} \\
(\mu \mathrm{M})\end{array}$ & $\begin{array}{l}\text { Staphylococcus aureus } \mathrm{MIC}_{99} \\
(\mu \mathrm{M})\end{array}$ \\
\hline 20 & 1.0 & 2.5 & $>100$ & 10 \\
\hline 33 & 0.25 & 12.5 & $>100$ & $>100$ \\
\hline
\end{tabular}

doi:10.1371/journal.pone.0155209.t001 


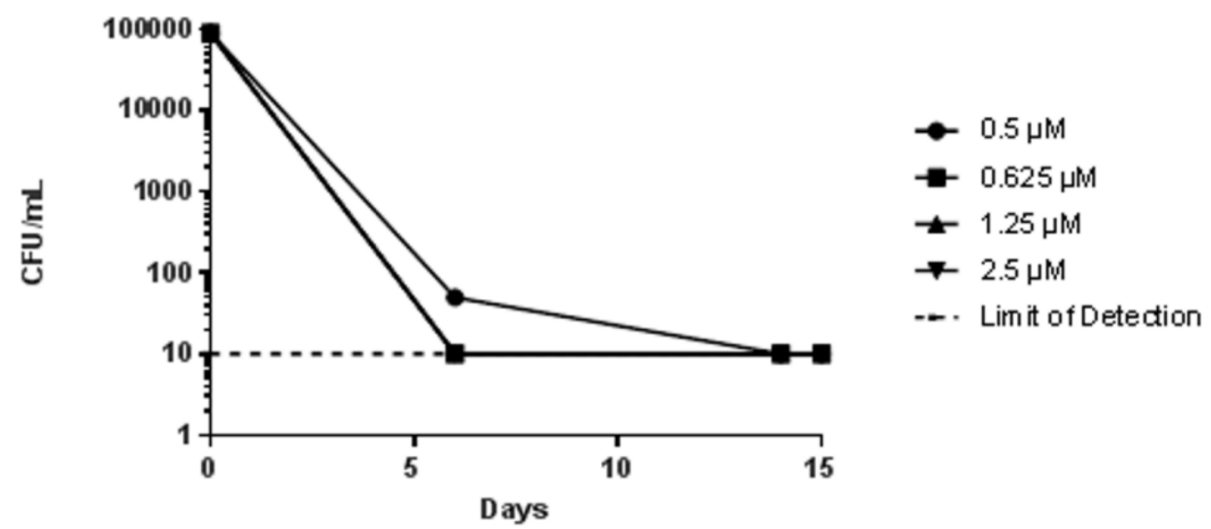

Fig 10. The representative aminothiazole 20 possesses bactericidal activity. $M$. tuberculosis was inoculated to a starting of $\mathrm{OD}_{590}$ of 0.1 in medium containing compound 20 . CFU/mL was enumerated at indicated time points by serial dilution onto solid medium. The limit of detection was 20 . Note that the lines for $0.625,1.25$ and 2.5 overlap.

doi:10.1371/journal.pone.0155209.g010

\section{Lack of iron chelating activity}

Due to the proximity of the heteroatomic pyridine and an electron-rich aminothiazole ring system, these aminothiazoles have the potential to chelate iron via the coordination of iron to the nitrogen atoms of both the pyridine and aminothiazole rings. This could be the mechanism of activity against $M$. tuberculosis, since iron is an essential nutrient for bacterial growth. To determine whether this is the case, we measured the capability of the representative compound 20 to inhibit growth in the presence of excess iron (Fig 11); we monitored growth over 7 days in six different concentrations bracketing the MIC in larger scale culture (growth tubes). As expected compound 20 completely prevented bacterial growth at the highest concentrations $(2-5 \mu \mathrm{M})$; growth was also inhibited at $1 \mu \mathrm{M}$. When additional iron was provided there was no growth at concentrations of $1-5 \mu \mathrm{M}$, thus demonstrating that iron was not available to overcome compound-mediated inhibition and in fact if anything, the bacteria were slightly more susceptible.

We also tested iron supplementation in the form of hemin on solid medium with compound 20 and three other compounds, but no difference in MIC was seen (data not shown). This

A

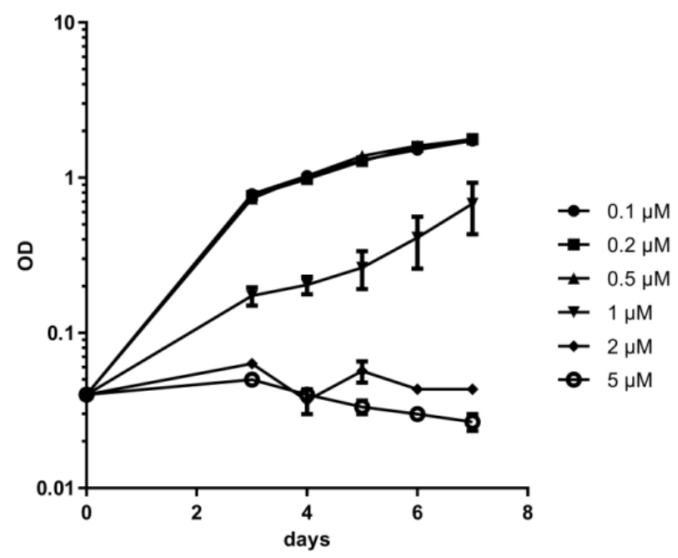

B

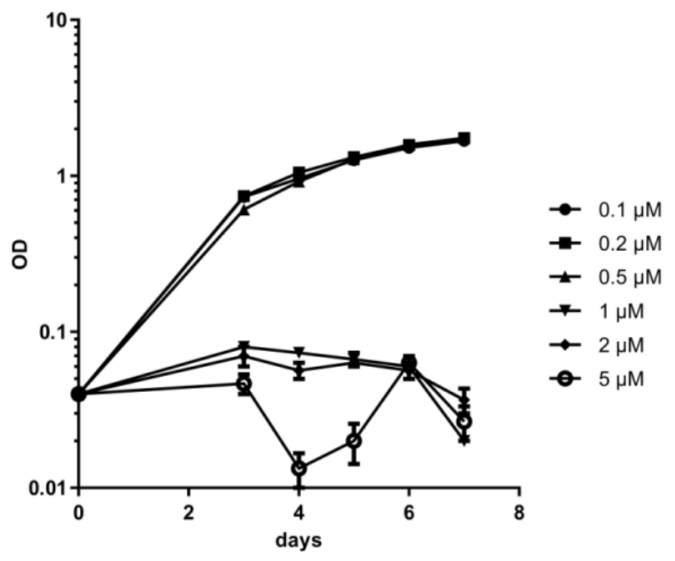

Fig 11. Inhibition of $M$. tuberculosis growth by AT compound 20. Growth curve in standard medium. (B) Growth curve in medium plus additional $0.04 \mathrm{~g} / \mathrm{L}$ ferric ammonium citrate. Cells were inoculated to a starting $\mathrm{OD}_{590}$ of 0.04 into growth medium. Data are the mean +/- standard deviation of three independent cultures.

doi:10.1371/journal.pone.0155209.g011 
suggests that chelation of iron from the medium is not the mechanism of action for this class of compounds.

\section{Conclusions}

Chemical library screening has successfully identified a number of compounds with excellent activity against $M$. tuberculosis including the 2-aminothiazoles [5]. We conducted an SAR assessment of different substitutions at the C-2 and C-4 positions, as well as possible replacements for the thiazole core. These modifications are in agreement with other aminothiazole analogs reported previously $[10,11]$. Concurrent with previous studies, a 2-pyridyl moiety at the C-4 position is essential for bacterial activity, as replacement of the pyridine ring resulted in a loss of activity. The efforts around the $\mathrm{C}-2$ position indicate flexibility to various modifications with amine and amide all showing activity. 4-(Pyridin-2-yl)- $N$-(pyridin-3-yl)thiazol2 -amine (20) was the most potent analog prepared. Unfortunately, as with other active compounds presented in this manuscript and those reported previously [10,11], the activity and cytotoxicity of $\mathbf{2 0}$ are strongly correlated. However, a few analogs demonstrated improved selectivity. Amide-linked phenyl substituents at the C-2 position provided potent analogs with good separation of cytotoxicity, similar to what has been previously reported [10]. In this study, compound 33, consisting of a 4-tert-butylbenzamide at the C-2 position, gave an MIC of $0.30 \mu \mathrm{M}$ and a selectivity index of $\sim 28$ suggesting that cytotoxicity can be dialed out of the series. Urea-linkages at the C-2 position were not previously reported, but we demonstrated that they also have good potency and some selectivity. We also demonstrated that some ketones and carboxamide residues can confer moderate activity. This expands the opportunities for structure-property relationship (SPR) studies and property modulation for in vivo studies.

Representative compounds demonstrated selectivity towards mycobacteria, suggesting a target that is restricted to this genus. In kill kinetic studies, the representative compound $\mathbf{2 0}$ was bactericidal with rapid killing of the bacteria and complete culture sterilization in 7 days. These findings suggest targeting of a particularly vulnerable and essential enzyme or pathway in the bacterium. Although the mechanism of action for the compound series remains unknown, we confirmed that it is not likely to result from iron chelation in the medium. Thus, further development of the AT series is promising.

\section{Materials \& Methods \\ Determination of minimum inhibitory concentration (MIC)}

MICs were determined against $M$. tuberculosis $\mathrm{H} 37 \mathrm{Rv}$ (London Pride) [15] grown in Middlebrook 7H9 medium containing 10\% OADC (oleic acid, albumin, dextrose, catalase) supplement (Becton Dickinson) and 0.05\% w/v Tween 80 (7H9-Tw-OADC) under aerobic conditions. Bacterial growth was measured by OD after 5 days of incubation at $37^{\circ} \mathrm{C}$. The MIC was defined as the minimum concentration at which growth was completely inhibited and was calculated from the inflection point of the fitted curve to the lower asymptote (zero growth).

\section{Cytotoxicity assay}

The Vero cell line (African green monkey kidney epithelial cells: ATCC CRL-1587) was grown in DMEM, High Glucose, GlutaMAX ${ }^{\mathrm{m}}$ (Invitrogen), 10\% fetal bovine serum (FBS), and 1X penicillin-streptomycin solution $(100 \mathrm{U} / \mathrm{mL})$. Compounds were solubilized in DMSO and assayed as a 10-point three-fold serial dilution. Compounds were incubated with cells for 2 days at $37^{\circ} \mathrm{C}, 5 \% \mathrm{CO}_{2}$. CellTiter-Glo $\AA$ Reagent (Promega) was added and relative luminescent 
units (RLU) measured. Inhibition curves were fitted using the Levenberg-Marquardt algorithm. $\mathrm{TC}_{50}$ is the compound concentration that gave $50 \%$ inhibition of growth.

\section{Activity spectrum}

The serial proportion method was used to determine $\mathrm{MIC}_{99}$ on solid medium [16]. LB was used for E. coli and S. aureus. Middlebrook 7H10 supplemented with 10\% v/v OADC was used for mycobacteria. E. coli and S. aureus were incubated at $37^{\circ} \mathrm{C}$ overnight. M. smegmatis was incubated at $37^{\circ} \mathrm{C}$ for 3 days. The $\mathrm{MIC}_{99}$ was the lowest concentration of compound, which yielded less than $1 \%$ growth.

\section{Kill kinetics}

A late $\log$ phase $\left(\mathrm{OD}_{590} 0.6-1.0\right)$ culture of $M$. tuberculosis (H37Rv) was adjusted to $\mathrm{OD}_{590} 0.1$ in 7H9-Tw-OADC; $50 \mu \mathrm{L}$ was used to inoculate $5 \mathrm{~mL} 7 \mathrm{H} 9-\mathrm{Tw}-\mathrm{OADC}\left(10^{5} \mathrm{CFU} / \mathrm{mL}\right)$. Compound was added to each tube to a final DMSO concentration of $2 \%$. Cultures were incubated at $37^{\circ} \mathrm{C}$ and serial dilutions plated on $7 \mathrm{H} 10$ agar plates to determine $\mathrm{CFU} / \mathrm{mL}$. Plates were incubated for 4 weeks before colonies were counted.

\section{Growth curves}

Growth curves were conducted in $5 \mathrm{~mL}$ of 7H9-Tw-OADC in $16 \times 125 \mathrm{~mm}$ glass tubes with stir bars. M. tuberculosis was inoculated to a theoretical starting $\mathrm{OD}_{590}$ of $0.04 . \mathrm{OD}_{590}$ was measured daily.

\section{Compound synthesis}

${ }^{1} \mathrm{H}$ and NMR spectral data were recorded in $\mathrm{CDCl}_{3}$ or DMSO- $\mathrm{d}_{6}$ on a 300 or $400 \mathrm{MHz}$ Bruker NMR spectrometer. Column chromatography was conducted on Revelaris flash chromatography system. Reactions were monitored using thin-layer chromatography (TLC) on silica gel plates. HPLC analysis was conducted on an Agilent 1100 series LC system (Agilent ChemStation Rev.A.10.02; Phenomenex-Luna-C18, $4.8 \mathrm{~mm} \times 150 \mathrm{~mm}, 5 \mu \mathrm{m}, 1.0 \mathrm{~mL} / \mathrm{min}$, UV 254nm, room temperature) with $\mathrm{MeCN} / \mathrm{H}_{2} \mathrm{O}(0.05 \% \mathrm{TFA}$ or $\mathrm{HCOOH}$ buffer) gradient elution. HPLC-MS was performed on a Gilson 321 HPLC with detection performed by a Gilson 170 DAD and a Finnigan AQA mass spectrometer operating in electrospray ionization mode using a Phenomenex Gemini C18 150x4.6mm column. Compound purity was determined using an Agilent 1100 series LC system (Agilent ChemStation Rev.A.10.02; Phenomenex-Luna-C18, 4.8 $\mathrm{mm} \times 150 \mathrm{~mm}, 5 \mu \mathrm{m}, 1.0 \mathrm{~mL} / \mathrm{min}$, UV $254 \mathrm{~nm}$, room temperature) with $\mathrm{MeCN} / \mathrm{H}_{2} \mathrm{O}(0.05 \%$ TFA or $\mathrm{HCOOH}$ buffer) gradient elution. All compounds were $>95 \%$ pure via LC/MS analysis.

2-Bromo-1-(pyridin-2-yl)ethan-1-one hydrobromide (3). To a solution of 1-(pyridin2-yl)ethan-1-one (3.0 g, $24.8 \mathrm{mmol})$ in $\mathrm{HBr}$ in $\mathrm{AcOH}(30 \mathrm{~mL})$ at $0^{\circ} \mathrm{C}$, bromine $(3.9 \mathrm{~g}, 24.8$ $\mathrm{mmol}$ ) was added drop wise and allowed the mixture to stir at $70^{\circ} \mathrm{C}$ for 3 hours. After TLC showed completion, diluted the mixture with diethyl ether $(50 \mathrm{~mL})$ and filtered and washed with diethyl ether to obtain 2-bromo-1-(pyridin-2-yl)ethan-1-one hydrobromide 3 (6.5 g, 93\% yield), as cream colored solid; ${ }^{1} \mathrm{H}$ NMR (400 MHz, DMSO-d $\left.\mathrm{d}_{6}\right): \delta 5.02(\mathrm{~s}, 2 \mathrm{H}), 7.73(\mathrm{~m}, 1 \mathrm{H})$, $8.01(\mathrm{~m}, 2 \mathrm{H}), 8.75(\mathrm{~d}, J=4.4 \mathrm{~Hz}, 1 \mathrm{H})$. All data are consistent with literature values [17].

2-(Adamantane-1-carboxamido)- $N$-methoxy- $N$-methylthiazole-4-carboxamide (7). To a solution of ethyl 2-aminothiazole-4-carboxylate $(2.0 \mathrm{~g}, 11.63 \mathrm{mmol})$ in DCM $(50 \mathrm{~mL})$, adamantane-1-carboxylic acid (2.0 g, $11.63 \mathrm{mmol})$, PyBOP (18.1 g, $34.8 \mathrm{mmol})$, DIPEA (5 mL) and DMF $(2 \mathrm{~mL})$ were added and stirred at room temperature for $16 \mathrm{~h}$. After completion, the 
reaction mixture was diluted with water $(100 \mathrm{~mL})$ and extracted with DCM $(3 \times 200 \mathrm{~mL})$. The organic layer was dried over sodium sulfate and concentrated. The resulting crude was purified by column chromatography on silica gel (100-200 mesh) using 30\% EtOAc in hexane as eluent to obtain 7 as a colorless oil (3.2 g, 84.2\%). ${ }^{1} \mathrm{H}$ NMR (400 MHz, MeOD): $\delta 7.94(\mathrm{~s}, 1 \mathrm{H}), 4.36(\mathrm{q}$, $J=7.2 \mathrm{~Hz}, 2 \mathrm{H}), 2.09(\mathrm{~m}, 3 \mathrm{H}), 2.00(\mathrm{~s}, 6 \mathrm{H}), 1.82(\mathrm{~m}, 6 \mathrm{H}), 1.38(\mathrm{t}, J=7.2 \mathrm{~Hz}, 3 \mathrm{H})$.

$\mathrm{MS} \mathrm{m} / \mathrm{z}(\mathrm{M}+\mathrm{H}) 335.25$.

$\mathrm{N}$-(2,6-Dimethylphenyl)-2-picolinoylhydrazine-1-carbothioamide (10). To a solution of picolinohydrazide (500 mg, $3.65 \mathrm{mmol})$ in ethanol $(10 \mathrm{~mL}), 2$-isothiocyanato-1,3-dimethylbenzene ( $595 \mathrm{mg}, 3.65 \mathrm{mmol}$ ) was added and the mixture was refluxed for $15 \mathrm{~h}$. After TLC showed completion, distilled off the solvent and the residue was washed with diethyl ether to obtain 10 (1.0 g, 91\% yield), as off-white solid, which was used without further purification; MS m/z (M+H) 301.23.

6-Chloro- $\mathrm{N}$-(2,6-dimethylphenyl)pyrimidin-4-amine (12). To a solution of 4,6-dichloropyrimidine 11 (1.0 g, $6.0 \mathrm{mmol})$ and 2,6-dimethylaniline $(0.81 \mathrm{~g}, 6.0 \mathrm{mmol})$ in isopropanol (5 $\mathrm{mL}$ ) in seal tube, catalytic $\mathrm{HCl}(0.1 \mathrm{~mL})$ was added and heated the sealed contents at $100^{\circ} \mathrm{C}$ for 16 hours. After TLC showed completion, reaction mixture was concentrated under vacuum. The residue was diluted with water $(5 \mathrm{~mL})$ and extracted with EtOAc $(3 \times 20 \mathrm{~mL})$. The organic layer was dried over $\mathrm{Na}_{2} \mathrm{SO}_{4}$ and concentrated. The resulting residue was purified by flash column chromatography and the desired product was eluted with 5\% EtOAc in hexane. Concentration of the pure fractions afforded $12\left(400 \mathrm{mg}, 25 \%\right.$ yield), as a light-brown solid; ${ }^{1} \mathrm{H}$ NMR (400 MHz, DMSO-d $\left.\mathrm{d}_{6}\right): \delta 2.20(\mathrm{~s}, 6 \mathrm{H}), 5.90(\mathrm{~m}, 1 \mathrm{H}), 6.71$ (brs, $\left.1 \mathrm{H}\right), 7.26-7.16(\mathrm{~m}, 2 \mathrm{H}), 7.36(\mathrm{~s}$, $1 \mathrm{H}), 8.42(\mathrm{~s}, 1 \mathrm{H})$; LCMS m/z $(\mathrm{M}+\mathrm{H})$ 234.27, purity: $97.1 \%$.

1-(2-Pyridyl)-1H-pyrazole-3-amine (15). To $t$-BuOK (12 mL, $12 \mathrm{mmol})$ in $t$ - $\mathrm{BuOH}$ (50 $\mathrm{mL}$ ) was added 2 -hydrazinopyridine $(1.09 \mathrm{~g}, 10 \mathrm{mmol})$. To the mixture was added methoxyacrylonitrile $(0.84 \mathrm{~mL}, 10 \mathrm{mmol})$ in $t-\mathrm{BuOH}(10 \mathrm{~mL})$. The mixture was stirred under reflux conditions and the reaction was monitored via LC/MS. After $3 \mathrm{~h}$, the reaction was cooled to room temperature and the solvent was removed. The resulting crude was suspended in water. The aqueous layer was extracted using EtOAc $(3 \times 50 \mathrm{~mL})$. The organic layers were collected, dried over $\mathrm{Na}_{2} \mathrm{SO}_{4}$ and concentrated in vacuo. The resulting crude was purified via flash column chromatography to give $\mathbf{1 5}$ (113 mg, 7\% yield), as yellow solid; ${ }^{1} \mathrm{H}$ NMR: $\left(300 \mathrm{MHz}, \mathrm{CD}_{3} \mathrm{OD}\right)$ : $\delta 5.25(\mathrm{~s}, 2 \mathrm{H}), 5.79-5.80(\mathrm{~m}, 1 \mathrm{H}), 7.11-7.15(\mathrm{~m}, 1 \mathrm{H}), 7.57(\mathrm{~d}, J=8.2 \mathrm{~Hz}, 1 \mathrm{H}), 7.82-7.88(\mathrm{~m}$, $1 \mathrm{H}), 8.25(\mathrm{~d}, J=3.5 \mathrm{~Hz}, 1 \mathrm{H}), 8.31-8.33(\mathrm{~m}, 1 \mathrm{H})$. All data are consistent with literature values $[17,18]$.

2-Amino-4-(pyridin-2-yl)thiazole (16). To 2-bromo-1-pyridin-2-yl-ethanone (1 g, 5 $\mathrm{mmol}$ ) in ethanol was added thiourea $(340 \mathrm{mg}, 5.1 \mathrm{mmol})$. The mixture was stirred at $70^{\circ} \mathrm{C}$. The reaction was monitored via LC/MS. After $2 \mathrm{~h}$, the reaction mixture was cooled to room temperature and precipitate was formed. The precipitate was collected by vacuum filtration and washed with acetone. The solid was dissolved in $2 \mathrm{M} \mathrm{NaOH}(25 \mathrm{~mL})$ and extracted with EtOAc $(3 \times 50 \mathrm{~mL})$. The combined organic layers were dried over $\mathrm{Na}_{2} \mathrm{SO}_{4}$ and concentrated in vacuo to give 3 (497 mg, $56 \%$ yield), as an off-white solid. ${ }^{1} \mathrm{H}$ NMR: $\left(300 \mathrm{MHz}, \mathrm{CD}_{3} \mathrm{OD}\right): \delta$ 7.24-7.31 (m, 2H), 7.80-7.92 (m, 2H), 8.49-8.51 (m, 1H); $\left.{ }^{13} \mathrm{C} \mathrm{NMR:} \mathrm{(300} \mathrm{MHz,} \mathrm{CD}_{3} \mathrm{OD}\right): \delta$ $105.9,120.8,122.3,137.3,148.5,149.5,152.4$; HRMS MS ESI $m / z$ calcd for $\mathrm{C}_{8} \mathrm{H}_{7} \mathrm{~N}_{3} \mathrm{~S}(\mathrm{M}+\mathrm{H})^{+}$ 178.0433 , found $178.0441(\Delta 0.8 \mathrm{ppm})$. All data are consistent with literature values [19].

General synthesis (procedure I) for compounds 17-29 and 43-61. Compounds 17-29 and 43-61 were prepared following this general protocol unless otherwise noted. To substituted 2-bromoethanone in ethanol was added substituted thiourea (1.02 eq). The mixture was stirred at $70^{\circ} \mathrm{C}$. The reaction was monitored via LC/MS. After $2 \mathrm{~h}$, the reaction mixture was cooled to room temperature and precipitate was formed. The precipitate was collected by vacuum filtration and washed with acetone. The solid was dissolved in $2 \mathrm{M} \mathrm{NaOH}(25 \mathrm{~mL})$ and 
extracted with EtOAc $(3 \times 50 \mathrm{~mL})$. The combined organic layers were dried over $\mathrm{Na}_{2} \mathrm{SO}_{4}$ and concentrated in vacuo desired product.

$N$-(2,6-Difluorophenyl)-4-(pyridin-2-yl)thiazol-2-amine (17). $23 \mathrm{mg}, 79 \%$ yield, as white solid; ${ }^{1} \mathrm{H}$ NMR: $\left(300 \mathrm{MHz}, \mathrm{CDCl}_{3}\right): \delta 6.99-7.05(\mathrm{t}, J=8.1 \mathrm{~Hz}), 7.16-7.28(\mathrm{~m}, 3 \mathrm{H}), 7.44$ (s, $1 \mathrm{H}), 7.67-7.72(\mathrm{~m}, 1 \mathrm{H}), 7.91(\mathrm{~d}, J=7.9 \mathrm{~Hz}, 1 \mathrm{H}), 8.56-8.58(\mathrm{~s}, 1 \mathrm{H}) ;{ }^{13} \mathrm{C}$ NMR: $(300 \mathrm{MHz}$, $\left.\mathrm{CDCl}_{3}\right): \delta 107.9,111.93,111.99,112.0,112.2,112.3,120.8,122.4,126.5,126.6,126.8,136.8$, 149.3; HRMS MS ESI $m / z$ calcd for $\mathrm{C}_{14} \mathrm{H}_{9} \mathrm{~F}_{2} \mathrm{~N}_{3} \mathrm{~S}(\mathrm{M}+\mathrm{H})^{+} 290.0558$, found $290.0543(\Delta$ $1.5 \mathrm{ppm})$.

$\mathrm{N}$-(2-Trifluoromethyl)-4-(pyridin-2-yl)thiazol-2-amine (18). $19 \mathrm{mg}, 59 \%$ yield, as white solid; ${ }^{1} \mathrm{H}$ NMR: $\left(300 \mathrm{MHz}, \mathrm{CDCl}_{3}\right): \delta$ 7.12-7.28 (m, 2H), $7.41(\mathrm{br} \mathrm{s}, 1 \mathrm{H}), 7.58-7.68(\mathrm{~m}, 2 \mathrm{H})$, $7.74-7.80(\mathrm{~m}, 1 \mathrm{H}), 8.00(\mathrm{~d}, J=7.9 \mathrm{~Hz}, 1 \mathrm{H}), 8.19(\mathrm{~d}, J=8.3 \mathrm{~Hz}, 1 \mathrm{H}), 8.62-8.64(\mathrm{~m}, 1 \mathrm{H}) ;{ }^{13} \mathrm{C}$ NMR: (300 MHz, $\mathrm{CDCl}_{3}$ ): $\delta$ 107.6, 120.3, 121.0, 122.6, 122.8, 126.7, 126.8, 133.24, 133.25, $136.9,149.4,163.6$; HRMS MS ESI $m / z$ calcd for $\mathrm{C}_{16} \mathrm{H}_{15} \mathrm{~N}_{3} \mathrm{~S}(\mathrm{M}+\mathrm{H})^{+} 322.062$, found 322.0602 $(\Delta 1.8 \mathrm{ppm})$.

$\mathrm{N}$-(2,6-Dimethylphenyl)-4-(pyridin-2-yl)thiazol-2-amine (19). $16 \mathrm{mg}, 57 \%$ yield, as beige crystals; ${ }^{1} \mathrm{H}$ NMR: $\left(300 \mathrm{MHz}, \mathrm{CDCl}_{3}\right): \delta 1.60(\mathrm{~s}, 6 \mathrm{H}), 2.35(\mathrm{~s}, 6 \mathrm{H}), 6.80(\mathrm{br} \mathrm{s}, 1 \mathrm{H}), 7.17-$ $7.24(\mathrm{~m}, 5 \mathrm{H}), 7.69-7.74(\mathrm{~m}, 1 \mathrm{H}), 7.90(\mathrm{~d}, J=7.9 \mathrm{~Hz}, 1 \mathrm{H}), 8.60-8.61(\mathrm{~m}, 1 \mathrm{H}) ;{ }^{13} \mathrm{C}$ NMR: $(300$ $\left.\mathrm{MHz}, \mathrm{CDCl}_{3}\right): \delta 18.2,106.1,120.6,122.3,128.1,136.7,149.4$; HRMS MS ESI $m / z$ calcd for $\mathrm{C}_{16} \mathrm{H}_{15} \mathrm{~N}_{3} \mathrm{~S}(\mathrm{M}+\mathrm{H})^{+} 282.1059$, found $282.1039(\Delta 2 \mathrm{ppm})$.

4-(Pyridin-2-yl)- $\mathrm{N}$-(pyridin-3-yl)thiazol-2-amine (20). To a solution of 1-(pyridin-3-yl) thiourea $(0.2 \mathrm{~g}, 1.3 \mathrm{mmol})$ in DMF (6 mL), 2-bromo-1-(pyridin-2-yl)ethan-1-one hydrobromide $3(0.55 \mathrm{~g}, 1.95 \mathrm{mmol})$ and triethylamine $(0.53 \mathrm{~mL}, 3.9 \mathrm{mmol})$ were added successively and heated the mixture at $70^{\circ} \mathrm{C}$ for 2 hours. After TLC showed completion, reaction mixture was diluted with EtOAc $(20 \mathrm{~mL})$ and washed with water $(3 \times 10 \mathrm{~mL})$. The organic layer was dried over $\mathrm{Na}_{2} \mathrm{SO}_{4}$ and concentrated. The resulting residue was purified by column chromatography (silicagel, 100-200\#) and the desired product was eluted with $2.5 \% \mathrm{CH}_{3} \mathrm{OH}$ in $\mathrm{CH}_{2} \mathrm{Cl}_{2}$. Concentration of the pure fractions afforded 20 (230 mg, 68\% yield), as a white solid; ${ }^{1} \mathrm{H}$ NMR: (400 MHz, DMSO-d $\left.\mathrm{d}_{6}\right): \delta 7.31-7.34(1 \mathrm{H}, \mathrm{m}), 7.38-7.41(1 \mathrm{H}, \mathrm{m}), 7.613(1 \mathrm{H}, \mathrm{s}), 7.88-7.93(1 \mathrm{H}$, m), $8.02(1 \mathrm{H}, \mathrm{d}, J=7.6 \mathrm{~Hz}), 8.18-8.20(1 \mathrm{H}, \mathrm{m}), 8.30-8.33(1 \mathrm{H}, \mathrm{m}), 8.58(1 \mathrm{H}, \mathrm{d}, J=4 \mathrm{~Hz}), 8.85$ $(1 \mathrm{H}, \mathrm{d}, J=2.4 \mathrm{~Hz}), 10.53(1 \mathrm{H}, \mathrm{s}) ;{ }^{13} \mathrm{C}$ NMR: $\left(300 \mathrm{MHz}, \mathrm{CDCl}_{3}\right): \delta 110.0,110.4,116.4,120.5$, 122.4, 136.8, 137.7, 146.8, 149.5; LCMS m/z $(\mathrm{M}+\mathrm{H})$ 255.04, purity 99.9\%; HRMS MS ESI $\mathrm{m} / z$ calcd for $\mathrm{C}_{13} \mathrm{H}_{10} \mathrm{~N}_{4} \mathrm{~S}(\mathrm{M}+\mathrm{H})^{+} 255.0699$, found $255.0681(\Delta 1.8 \mathrm{ppm})$.

$\mathrm{N}$-(Phenyl)-4-(pyridin-2-yl)thiazol-2-amine (21). $13 \mathrm{mg}, 52 \%$ yield, as beige crystals; ${ }^{1} \mathrm{H}$ NMR: $\left(300 \mathrm{MHz}, \mathrm{CDCl}_{3}\right): \delta$ 7.08-7.13 (m, 1H), 7.20-7.24 (m, 1H), 7.36-7.44 (m, 6H), 7.74$7.79(\mathrm{~m}, 1 \mathrm{H}), 8.00(\mathrm{~d}, J=8.0 \mathrm{~Hz}, 1 \mathrm{H}), 8.62-8.63(\mathrm{~m}, 1 \mathrm{H}) ;{ }^{13} \mathrm{C} \mathrm{NMR:}\left(300 \mathrm{MHz}, \mathrm{CDCl}_{3}\right): \delta$ 106.3, 118.1, 120.9, 122.5, 123.0, 129.5, 136.9, 149.4; HRMS MS ESI $m / z$ calcd for $\mathrm{C}_{14} \mathrm{H}_{11} \mathrm{~N}_{3} \mathrm{~S}$ $(\mathrm{M}+\mathrm{H})^{+} 254.0746$, found $2254.073454 .0734(\Delta 1.2 \mathrm{ppm})$.

$\mathrm{N}$-(Pyridin-3-yl)-4-(pyridin-2-yl)thiazol-2-amine (22). $15 \mathrm{mg}, 62 \%$ yield, as white solid; ${ }^{1} \mathrm{H}$ NMR: (300 MHz, CD $\left.3 \mathrm{OD}\right): \delta 6.91-6.95(\mathrm{~m}, 1 \mathrm{H}), 7.02-7.04(\mathrm{~m}, 1 \mathrm{H}), 7.40(\mathrm{~s}, 1 \mathrm{H}), 7.46-7.51$ $(\mathrm{m}, 1 \mathrm{H}), 7.67-7.72(\mathrm{~m}, 1 \mathrm{H}), 8.34(\mathrm{~m}, 1 \mathrm{H}), 8.45-8.47(\mathrm{~m}, 1 \mathrm{H}), 9.12(\mathrm{br} a, 1 \mathrm{H}) ;{ }^{13} \mathrm{C}$ NMR: $(300$ $\left.\mathrm{MHz}, \mathrm{CD}_{3} \mathrm{OD}\right): \delta 107.1,110.2,115.8,123.8,133.7,137.5,146.2,147.1$; HRMS MS ESI $m / z$ calcd for $\mathrm{C}_{13} \mathrm{H}_{10} \mathrm{~N}_{4} \mathrm{~S}(\mathrm{M}+\mathrm{H})^{+} 255.0699$, found $255.0678(\Delta 2.1 \mathrm{ppm})$.

$\mathrm{N}$-(2-Methoxyphenyl)-4-(pyridin-2-yl)thiazol-2-amine (23). To a solution of 1-(2-methoxyphenyl)thiourea (200 mg, $1.09 \mathrm{mmol}$ ) in DMF (6 mL), 2-bromo-1-(pyridin-2-yl)ethan1-one hydrobromide 3 ( $460 \mathrm{mg}, 1.64 \mathrm{mmol}$ ) and triethylamine $(0.45 \mathrm{~mL}, 3.29 \mathrm{mmol}$ ) were added successively and heated the mixture at $70^{\circ} \mathrm{C}$ for 2 hours. After TLC showed completion, reaction mixture was diluted with EtOAc $(20 \mathrm{~mL})$ and washed with water $(3 \times 10 \mathrm{~mL})$. The organic layer was dried over $\mathrm{Na}_{2} \mathrm{SO}_{4}$ and concentrated. The resulting residue was purified by column chromatography (silica gel, 100-200\#) and the desired product was eluted with 20\% 
EtOAc in hexane. Concentration of the pure fractions afforded $\mathbf{2 3}$ (170 mg, 55\% yield), as a light-pink solid; ${ }^{1} \mathrm{H}$ NMR: (400 MHz, DMSO- $\left.\mathrm{d}_{6}\right): \delta 3.87(\mathrm{~s}, 3 \mathrm{H}), 6.98-7.05(\mathrm{~m}, 2 \mathrm{H}), 7.28-7.32$ $(\mathrm{m}, 1 \mathrm{H}), 7.51(\mathrm{~s}, 1 \mathrm{H}), 7.86-7.90(\mathrm{~m}, 1 \mathrm{H}), 7.97(\mathrm{~d}, J=7.6 \mathrm{~Hz}, 1 \mathrm{H}), 8.51-8.54(\mathrm{~m}, 1 \mathrm{H}), 8.56-8.58$ (m, $1 \mathrm{H}), 9.75$ (s, $1 \mathrm{H}) ;{ }^{13} \mathrm{C}$ NMR: $\left(300 \mathrm{MHz}, \mathrm{CDCl}_{3}\right): \delta 55.7,106.3,110.1,116.2,121.0,121.0$, 121.1, 121.9, 122.4, 129.9, 136.8, 147.3, 149.3, 151.2, 152.7, 163.5; LCMS m/z (M+H) 284.08, purity 99.9\%; HRMS MS ESI $m / z$ calcd for $\mathrm{C}_{15} \mathrm{H}_{13} \mathrm{~N}_{3} \mathrm{OS}(\mathrm{M}+\mathrm{H})^{+} 284.0852$, found $284.084(\Delta$ $1.2 \mathrm{ppm})$.

4-(Pyridin-2-yl)- $\boldsymbol{N}$-(pyridin-4-yl)thiazol-2-amine(24). $14 \mathrm{mg}$, 58\% yield, as off-white solid; ${ }^{1}$ H NMR: (400 MHz, DMSO-d ${ }_{6}$ ): $\delta$ 7.32-7.36 (m, 1H), 7.68-7.70 (m, 3H), 7.90-7.94 (m, $1 \mathrm{H}), 8.05(\mathrm{~d}, J=7.6 \mathrm{~Hz}, 1 \mathrm{H}), 8.42(\mathrm{~d}, J=6.4 \mathrm{~Hz}, 1 \mathrm{H}), 8.60(\mathrm{~d}, J=4 \mathrm{~Hz}, 1 \mathrm{H}), 10.80(1 \mathrm{H}, \mathrm{s}) ;{ }^{13} \mathrm{C}$ NMR: (300 MHz, DMSO-d $\left.\mathrm{d}_{6}\right): \delta 109.0,111.6,120.9,123.3,137.8,149.9,150.7,151.0,152.3$, 162.7; LCMS m/z (M+H) 255.04, purity 99.4\%; HRMS MS ESI $m / z$ calcd for $\mathrm{C}_{13} \mathrm{H}_{10} \mathrm{~N}_{4} \mathrm{~S}(\mathrm{M}$ $+\mathrm{H})^{+} 255.0699$, found $255.0674(\Delta 2.5 \mathrm{ppm})$.

$\mathrm{N}$-(Naphthalen-1-yl)-4-(pyridin-2-yl)thiazol-2-amine (25). To a solution of 1-(naphthalen-1-yl)thiourea $(0.2 \mathrm{~g}, 0.98 \mathrm{mmol}$ ) in DMF (10 mL), 2-bromo-1-(pyridin-2-yl)ethan-1-one hydrobromide $3(0.416 \mathrm{~g}, 1.48 \mathrm{mmol})$ and triethylamine $(0.41 \mathrm{~mL}, 2.96 \mathrm{mmol})$ were added successively and heated the mixture at $70^{\circ} \mathrm{C}$ for 2 hours. After TLC showed completion, reaction mixture was diluted with EtOAc $(20 \mathrm{~mL})$ and washed with water $(3 \times 10 \mathrm{~mL})$. The organic layer was dried over $\mathrm{Na}_{2} \mathrm{SO}_{4}$ and concentrated. The resulting residue was purified by column chromatography (silica gel, 230-400\#) and the desired product was eluted with $3 \%$ acetone in $\mathrm{CH}_{2} \mathrm{Cl}_{2}$. Concentration of the pure fractions afforded $25(30 \mathrm{mg}, 10 \%$ yield), as a brown solid; ${ }^{1} \mathrm{H}$ NMR: (400 MHz, DMSO-d $\left.\mathrm{d}_{6}\right): \delta 7.29-7.32(\mathrm{~m}, 1 \mathrm{H}), 7.53-7.59(\mathrm{~m}, 4 \mathrm{H}), 7.67(\mathrm{~d}, J=8 \mathrm{~Hz}$, $1 \mathrm{H}), 7.86-7.90(\mathrm{~m}, 1 \mathrm{H}), 7.93-7.98(\mathrm{~m}, 2 \mathrm{H}), 8.31-8.34(\mathrm{~m}, 1 \mathrm{H}), 8.36(\mathrm{~d}, J=7.6 \mathrm{~Hz}, 1 \mathrm{H}), 8.59(\mathrm{~d}$, $J=4.8 \mathrm{~Hz}, 1 \mathrm{H}), 10.12(\mathrm{~s}, 1 \mathrm{H}) ;{ }^{13} \mathrm{C}$ NMR: $\left(300 \mathrm{MHz}, \mathrm{DMSO}-\mathrm{d}_{6}\right): \delta 107.7,116.6,120.8,122.4$, $122.5,123.0,126.1,126.2,126.6,128.7,134.4,137.0,137.6,149.8,150.6,162.6,165.9 ;$ LCMS m/ $\mathrm{z}(\mathrm{M}+\mathrm{H}) 304.18$, purity $97.2 \%$. HRMS MS ESI $m / z$ calcd for $\mathrm{C}_{18} \mathrm{H}_{13} \mathrm{~N}_{3} \mathrm{~S}(\mathrm{M}+\mathrm{H})^{+} 304.0903$, found $304.089(\Delta 1.3 \mathrm{ppm})$.

$\mathrm{N}$-(4-tert-Butylphenyl)-4-(pyridin-2-yl)thiazol-2-amine (26). $136 \mathrm{mg}, 40 \%$ yield, as white solid; ${ }^{1} \mathrm{H}$ NMR: $\left(300 \mathrm{MHz}, \mathrm{CDCl}_{3}\right): \delta 1.34(\mathrm{~s}, 9 \mathrm{H}), 7.19-7.23(\mathrm{~m}, 1 \mathrm{H}), 7.33-7.41(\mathrm{~m}, 5 \mathrm{H})$, 7.61 (br s, $1 \mathrm{H}), 7.72-7.76(\mathrm{~m}, 1 \mathrm{H}), 7.99-8.02(\mathrm{~m}, 1 \mathrm{H}), 8.61-8.62(\mathrm{~m}, 1 \mathrm{H}) ;{ }^{13} \mathrm{C}$ NMR: $(300$ $\mathrm{MHz}, \mathrm{CDCl}_{3}$ ): $\delta 31.4,106.0,118.2,120.9$ 121.0, 122.4, 122.5, 126.3, 136.8, 137.7, 149.3; LCMS $\mathrm{m} / \mathrm{z}(\mathrm{M}+\mathrm{H}) 310.13$, purity $99.9 \%$; HRMS MS ESI $m / z$ calcd for $\mathrm{C}_{18} \mathrm{H}_{19} \mathrm{~N}_{3} \mathrm{~S}(\mathrm{M}+\mathrm{H})^{+} 310.1372$, found 310.1359 ( $\Delta 1.3 \mathrm{ppm})$.

$\mathrm{N}$-Cyclohexyl-4-(pyridin-2-yl)thiazol-2-amine (27). To a solution of 1-cyclohexylthiourea $(0.227 \mathrm{~g}, 1.44 \mathrm{mmol}$ ) in DMF (7 mL), 2-bromo-1-(pyridin-2-yl)ethan-1-one hydrobromide $3(0.350 \mathrm{~g}, 1.25 \mathrm{mmol})$ and triethylamine $(0.35 \mathrm{~mL}, 2.50 \mathrm{mmol})$ were added successively and heated the mixture at $70^{\circ} \mathrm{C}$ for 2 hours. After TLC showed completion, reaction mixture was diluted with EtOAc $(20 \mathrm{~mL})$ and washed with water $(3 \times 10 \mathrm{~mL})$. The organic layer was dried over $\mathrm{Na}_{2} \mathrm{SO}_{4}$ and concentrated. The resulting residue was purified by column chromatography (silica gel, 100-200\#) and the desired product was eluted with $5 \% \mathrm{CH}_{3} \mathrm{OH}$ in $\mathrm{CH}_{2} \mathrm{Cl}_{2}$. Concentration of the pure fractions afforded 27 ( $150 \mathrm{mg}, 46 \%$ yield), as a cream colored solid; ${ }^{1} \mathrm{H}$ NMR: (400 MHz, DMSO-d $\left.\mathrm{d}_{6}\right): \delta 1.20-1.36(\mathrm{~m}, 5 \mathrm{H}), 1.54-1.57(\mathrm{~m}, 1 \mathrm{H}), 1.68-1.72$ $(\mathrm{m}, 2 \mathrm{H}), 1.97-2.00(\mathrm{~m}, 2 \mathrm{H}), 3.47-3.53(\mathrm{~m}, 1 \mathrm{H}), 7.22-7.26(\mathrm{~m}, 2 \mathrm{H}), 7.63(\mathrm{~d}, J=7.6 \mathrm{~Hz}, 1 \mathrm{H})$, 7.79-7.86 (m, 2H), $8.53(\mathrm{~d}, J=6 \mathrm{~Hz}, 1 \mathrm{H}) ;{ }^{13} \mathrm{C}$ NMR: $\left(300 \mathrm{MHz}, \mathrm{CDCl}_{3}\right): \delta$ 24.7, 25.5, 33.0, 55.0, $104.9,120.8,122.2,136.7,149.3,152.9,168.8 ;$ LCMS m/z (M+H) 260.09, purity 99.5\%; HRMS MS ESI $m / z$ calcd for $\mathrm{C}_{14} \mathrm{H}_{17} \mathrm{~N}_{3} \mathrm{~S}(\mathrm{M}+\mathrm{H})^{+} 260.1216$, found $260.1201(\Delta 1.5 \mathrm{ppm})$.

4-(Pyridin-2-yl)-N-(4-(trifluoromethyl)phenyl)thiazol-2-amine (28). To a solution of 1(4-(trifluoromethyl)phenyl)thiourea $(0.270 \mathrm{~g}, 1.23 \mathrm{mmol})$ in DMF $(8 \mathrm{~mL})$, 2-bromo-1-(pyridin-2-yl)ethan-1-one hydrobromide $3(0.300 \mathrm{~g}, 1.07 \mathrm{mmol})$ and triethylamine $(0.3 \mathrm{~mL}, 2.14$ 
mmol) were added successively and heated the mixture at $70^{\circ} \mathrm{C}$ for 2 hours. After TLC showed completion, reaction mixture was diluted with EtOAc $(20 \mathrm{~mL})$ and washed with water $(3 \times 10$ $\mathrm{mL}$ ). The organic layer was dried over $\mathrm{Na}_{2} \mathrm{SO}_{4}$ and concentrated. The resulting residue was purified by column chromatography (silica gel, 100-200\#) and the desired product was eluted with 30\% EtOAc in hexane. Concentration of the pure fractions afforded 28 (65 mg, 19\% yield), as a cream colored solid; ${ }^{1} \mathrm{H}$ NMR: $\left(400 \mathrm{MHz}, \mathrm{DMSO}_{\mathrm{d}}\right)$ : $\delta 7.33-7.35(\mathrm{~m}, 1 \mathrm{H}), 7.65(\mathrm{~s}$, $1 \mathrm{H}), 7.71(\mathrm{~d}, J=8.8 \mathrm{~Hz}, 2 \mathrm{H}), 7.88-7.95(\mathrm{~m}, 3 \mathrm{H}), 8.05(\mathrm{~d}, J=8 \mathrm{~Hz}, 1 \mathrm{H}), 8.59-8.60(\mathrm{~m}, 1 \mathrm{H})$, 10.75 (s, 1H); ${ }^{13} \mathrm{C}$ NMR: $\left(300 \mathrm{MHz}\right.$, DMSO-d $\left.\mathrm{d}_{6}\right): \delta 108.4,117.0,120.9,123.2,126.7,126.81$, $126.87,137.7,144.7,149.9,150.8,152.4,163.1 ; \mathrm{LCMS} \mathrm{m} / \mathrm{z}(\mathrm{M}+\mathrm{H}) 322.05$, purity $99.5 \%$; HRMS MS ESI $m / z$ calcd for $\mathrm{C}_{15} \mathrm{H}_{10} \mathrm{~F}_{3} \mathrm{~N}_{3} \mathrm{~S}(\mathrm{M}+\mathrm{H})^{+} 322.062$, found $322.0607(\Delta 1.3 \mathrm{ppm})$.

$\mathrm{N}$-(Naphthalen-2-yl)-4-(pyridin-2-yl)thiazol-2-amine (29). A mixture of 1-(naphthalen2-yl)thiourea (110 mg, $0.54 \mathrm{mmol}$ ) in DMF ( $5 \mathrm{~mL}$ ), 2-bromo-1-(pyridin-2-yl)ethan-1-one hydrobromide 3 ( $229 \mathrm{mg}, 0.81 \mathrm{mmol})$ and triethylamine $(0.22 \mathrm{~mL}, 1.6 \mathrm{mmol})$ were added successively and heated the mixture at $70^{\circ} \mathrm{C}$ for 2 hours. After TLC showed completion, reaction mixture was diluted with EtOAc $(20 \mathrm{~mL})$ and washed with water $(3 \times 10 \mathrm{~mL})$. The organic layer was dried over $\mathrm{Na}_{2} \mathrm{SO}_{4}$ and concentrated. The resulting residue was purified by flash column chromatography and the desired product was eluted with $15.5 \%$ EtOAc in hexane. Concentration of the pure fractions afforded $29(85 \mathrm{mg}, 51 \%$ yield $)$, as a yellow solid; ${ }^{1} \mathrm{H}$ NMR: (300 MHz, DMSO-d $\left.\mathrm{d}_{6}\right): \delta 7.33-7.39(\mathrm{~m}, 2 \mathrm{H}), 7.46-7.50(\mathrm{t}, J=7.0 \mathrm{~Hz}, 1 \mathrm{H}), 7.58-759(\mathrm{~m}, 1 \mathrm{H})$, $7.62(\mathrm{~s}, 1 \mathrm{H}), 7.82-7.98(\mathrm{~m}, 4 \mathrm{H}), 8.12(\mathrm{~d}, J=7.8 \mathrm{~Hz}, 1 \mathrm{H}), 8.55(\mathrm{~s}, 1 \mathrm{H}), 8.60-8.62(\mathrm{~m}, 1 \mathrm{H}), 10.58$ (br s, $1 \mathrm{H}) ;{ }^{13} \mathrm{C}$ NMR: (300 MHz, DMSO-d $\mathrm{d}_{6}$ ): $\delta 107.5,112.0,119.4,120.9,123.1,124.2,126.9$, 127.5 127.9, 129.1, 129.2, 134.4, 137.8, 139.1, 149.9, 150.9, 152.5, 163.6; LCMS m/z (M+H) 304.07, purity $99.1 \%$; HRMS MS ESI $m / z$ calcd for $\mathrm{C}_{18} \mathrm{H}_{13} \mathrm{~N}_{3} \mathrm{~S}(\mathrm{M}+\mathrm{H})^{+} 304.0903$, found 3 $304.089504 .0895(\Delta 0.8 \mathrm{ppm})$.

General synthesis for compounds 30-40. Compounds 20-30 were prepared following this general procedure unless otherwise noted. To $\mathbf{5}$ dissolved in THF was added triethylamine $(1.0 \mathrm{eq})$. The mixture was cooled in an ice-bath, and to the mixture was added substituted acid chloride (1.0 eq). The mixture was stirred at room temperature and the reaction was monitored via LC/MS. After $1 \mathrm{~h}$, the reaction solvent was evaporated. The resulting crude was purified by recrystallization from ethanol or purified via flash column chromatography to give desired product.

2,2-Dimethyl- $\boldsymbol{N}$ - [4-(pyridin-2-yl)-1,3-thiazol-2-yl]propanamide (30). $14 \mathrm{mg}, 33 \%$ yield, as off-white solid; ${ }^{1} \mathrm{H}$ NMR: $\left(300 \mathrm{MHz}, \mathrm{CDCl}_{3}\right): \delta 1.37(\mathrm{~s}, 9 \mathrm{H}), 7.21-7.28(\mathrm{~m}, 1 \mathrm{H}), 7.65$ $(\mathrm{s}, 1 \mathrm{H}), 7.73-7.78(\mathrm{t}, J=7.7 \mathrm{~Hz}, 1 \mathrm{H}), 7.88(\mathrm{~d}, J=8.0 \mathrm{~Hz}, 1 \mathrm{H}), 8.65-8.66(\mathrm{~m}, 1 \mathrm{H}), 9.00(\mathrm{br} \mathrm{s}$, $1 \mathrm{H}) ;{ }^{13} \mathrm{C}$ NMR: $\left(300 \mathrm{MHz}, \mathrm{CDCl}_{3}\right): \delta 27.2,111.9,120.4,122.6,136.8,149.6$; HRMS MS ESI $m / z$ calcd for $\mathrm{C}_{13} \mathrm{H}_{15} \mathrm{~N}_{3} \mathrm{OS}(\mathrm{M}+\mathrm{H})^{+} 262.1009$, found $262.0998(\Delta 1.1 \mathrm{ppm})$.

$\mathrm{N}$ - [4-(Pyridin-2-yl)-1,3-thiazol-2-yl]acetamide (31). $16 \mathrm{mg}, 34 \%$ yield, as off-white solid; ${ }^{1} \mathrm{H}$ NMR: (300 MHz, $\left.\mathrm{CD}_{3} \mathrm{OD}\right): \delta 2.2517(\mathrm{~s}, 3 \mathrm{H}), 7.32-7.36(\mathrm{~m}, 1 \mathrm{H}), 7.74(\mathrm{br} \mathrm{s}, 1 \mathrm{H}), 7.86-$ $7.91(\mathrm{~m}, 1 \mathrm{H}), 8.07(\mathrm{~d}, J=8.0 \mathrm{~Hz}, 1 \mathrm{H}), 8.55-8.56(\mathrm{~m}, 1 \mathrm{H}) ;{ }^{13} \mathrm{C} \mathrm{NMR}:\left(300 \mathrm{MHz}, \mathrm{CD}_{3} \mathrm{OD}\right): \delta$ 21.1, 111.3, 121.0, 122.6, 137.4, 148.6; HRMS MS ESI $m / z$ calcd for $\mathrm{C}_{10} \mathrm{H}_{9} \mathrm{~N}_{3} \mathrm{OS}(\mathrm{M}+\mathrm{H})^{+}$ 220.0539 , found $220.0526(\Delta 1.3 \mathrm{ppm})$.

$\mathrm{N}$ - [4-(Pyridin-2-yl)-1,3-thiazol-2-yl]cyclopropanecarboxamide (32). $19 \mathrm{mg}, 43 \%$ yield, as off-white solid; ${ }^{1} \mathrm{H}$ NMR: $\left(300 \mathrm{MHz}, \mathrm{CDCl}_{3}\right): \delta 0.62-0.67(\mathrm{~m}, 2 \mathrm{H}), 1.06-1.09(\mathrm{~m}, 2 \mathrm{H}), 1.29-$ $1.35(\mathrm{~m}, 1 \mathrm{H}), 7.23-7.27(\mathrm{~m}, 1 \mathrm{H}), 7.71-7.79(\mathrm{~m}, 1 \mathrm{H}), 8.64-8.65(\mathrm{~m}, 1 \mathrm{H}), 11.4(\mathrm{br} \mathrm{s}, 1 \mathrm{H}) ;{ }^{13} \mathrm{C}$ NMR: (300 MHz, $\left.\mathrm{CDCl}_{3}\right): \delta 9.2,14.9,111.9,120.3,122.7,137.0,149.1,149.7,152.1,159.6$, 172.2; HRMS MS ESI $m / z$ calcd for $\mathrm{C}_{12} \mathrm{H}_{11} \mathrm{~N}_{3} \mathrm{OS}(\mathrm{M}+\mathrm{H})^{+} 246.0696$, found $246.0675(\Delta$ $2.1 \mathrm{ppm})$.

2-(tert-Butyl)- $N$ - [4-(pyridin-2-yl)-1,3-thiazol-2-yl]benzamide (33). $24 \mathrm{mg}, 70 \%$ yield, as a white solid; ${ }^{1} \mathrm{H}$ NMR: $\left(300 \mathrm{MHz}, \mathrm{DMSO}-\mathrm{d}_{6}\right): \delta 1.25(\mathrm{~s}, 9 \mathrm{H}), 7.33-7.37(\mathrm{t}, J=6.5 \mathrm{~Hz}, 1 \mathrm{H})$, 
$7.56(\mathrm{~d}, J=8.3 \mathrm{~Hz}, 2 \mathrm{H}), 7.89(\mathrm{~s}, 2 \mathrm{H}), 8.02-8.11(\mathrm{~m}, 3 \mathrm{H}), 8.61-8.63(\mathrm{~m}, 1 \mathrm{H}), 12.74(\mathrm{br} \mathrm{s}, 1 \mathrm{H})$;

${ }^{13}$ C NMR: (300 MHz, DMSO-d ${ }_{6}$ ): $\delta$ 19.1, 22.8, 26.5, 43.4, 63.5, 67.5, 109.2, 113.1, 114.9, 119.4 , 123.7, 131.5; HRMS MS ESI $m / z$ calcd for $\mathrm{C}_{19} \mathrm{H}_{19} \mathrm{~N}_{3} \mathrm{OS}(\mathrm{M}+\mathrm{H})^{+} 338.1249$, found 373.1660 parent ion not detected.

2-(Dimethylamino)- $N$ - [4-(pyridin-2-yl)-1,3-thiazol-2-yl] acetamide (34). $16 \mathrm{mg}, 39 \%$ yield, as brown solid; ${ }^{1} \mathrm{H}$ NMR: $\left(300 \mathrm{MHz}, \mathrm{CDCl}_{3}\right): \delta 7.69-7.37(\mathrm{~m}, 1 \mathrm{H}), 8.18(\mathrm{~s}, 1 \mathrm{H}), 8.29-$ $8.39(\mathrm{~m}, 2 \mathrm{H}), 8.69-8.71(\mathrm{~m}, 1 \mathrm{H}) ;{ }^{13} \mathrm{C}$ NMR: $\left(300 \mathrm{MHz}, \mathrm{CDCl}_{3}\right): \delta$ 43.3, 57.6, 116.1, 122.6, $124.2,124.3,142.3,144.5,144.6,158.1,163.5$; HRMS MS ESI $m / z$ calcd for $\mathrm{C}_{12} \mathrm{H}_{14} \mathrm{~N}_{4} \mathrm{OS}$ $(\mathrm{M}+\mathrm{H})^{+}$263.0961, found $263.0937(\Delta 2.4 \mathrm{ppm})$.

$\mathrm{N}$ - [4-(Pyridin-2-yl)-1,3-thiazol-2-yl]cyclohexanecarboxamide (35). $21 \mathrm{mg}, 48 \%$ yield, as white solid; ${ }^{1} \mathrm{H}$ NMR: $\left(300 \mathrm{MHz}, \mathrm{CDCl}_{3}\right): \delta 1.19-2.01(\mathrm{~m}, 10 \mathrm{H}), 2.46-2.54(\mathrm{~m}, 1 \mathrm{H}), 6.26(\mathrm{br}$ $\mathrm{s}, 3 \mathrm{H}), 7.54-7.59(\mathrm{~m}, 1 \mathrm{H}), 7.85(\mathrm{~s}, 1 \mathrm{H}), 8.07-8.18(\mathrm{~m}, 2 \mathrm{H}), 9.04(\mathrm{~m}, 1 \mathrm{H}) ;{ }^{13} \mathrm{C}$ NMR: $(300 \mathrm{MHz}$, $\left.\mathrm{CDCl}_{3}\right): \delta 25.3,25.5,29.0,44.7,116.2,122.1,123.9,142.3,144.8,147.5,160.2,175.2$; HRMS MS ESI $m / z$ calcd for $\mathrm{C}_{15} \mathrm{H}_{17} \mathrm{~N}_{3} \mathrm{OS}(\mathrm{M}+\mathrm{H})^{+} 288.1165$, found $288.1144(\Delta 2.1 \mathrm{ppm})$.

2-Oxo-2- [[4-(2-pyridinyl)-2-thiazolyl] amino]ethyl] ester acetic acid (36). $6 \mathrm{mg}, 24 \%$ yield, as waxy white solid; ${ }^{1} \mathrm{H}$ NMR: $\left(300 \mathrm{MHz}, \mathrm{DMSO}_{6}\right): \delta 2.14(\mathrm{~s}, 3 \mathrm{H}), 7.39(\mathrm{~m}, 1 \mathrm{H}), 7.90-$ $7.97(\mathrm{~m}, 3 \mathrm{H}), 8.63(\mathrm{~m}, 1 \mathrm{H}), 12.57(\mathrm{~s}, 1 \mathrm{H})$; HRMS MS ESI $m / z$ calcd for $\mathrm{C}_{12} \mathrm{H}_{11} \mathrm{~N}_{3} \mathrm{O}_{3} \mathrm{~S}(\mathrm{M}+\mathrm{H})^{+}$ 278.0594, found $278.0582(\Delta 1.2 \mathrm{ppm})$.

2-Hydroxy- $\mathrm{N}$ - [4-(2-pyridinyl)-2-thiazolyl]acetamide (37). To 36 (5 mg, $0.1 \mathrm{mmol}$ ) was added $5 \% \mathrm{~K}_{2} \mathrm{CO}_{3}$ in water $(2 \mathrm{~mL})$. The mixture was stirred at room temperature and the reaction was monitored via LC/MS. After $3 \mathrm{~h}$, the aqueous layer was extracted with EtOAc 3 × 25 $\mathrm{mL}$ ). The organic layers were collected, dried over $\mathrm{Na}_{2} \mathrm{SO}_{4}$ and concentrated in vacuo. The resulting crude was purified via flash column chromatography to give 37 (4 mg, 100\% yield), as a white solid; ${ }^{1} \mathrm{H}$ NMR: $\left(300 \mathrm{MHz}, \mathrm{DMSO}-\mathrm{d}_{6}\right): \delta 4.17(\mathrm{~s}, 2 \mathrm{H}), 7.35-7.39(\mathrm{~m}, 1 \mathrm{H}), 7.87-8.00$ $(\mathrm{m}, 3 \mathrm{H}), 8.60-8.62(\mathrm{~m}, 1 \mathrm{H}), 11.95$ (br s, $1 \mathrm{H})$; HRMS MS ESI $m / z$ calcd for $\mathrm{C}_{10} \mathrm{H}_{9} \mathrm{~N}_{3} \mathrm{O}_{2} \mathrm{~S}$ $(\mathrm{M}+\mathrm{H})^{+} 236.0488$, found $236.0500(\Delta 1.2 \mathrm{ppm})$.

4-Nitro- $\mathrm{N}$ - [4-(2-pyridinyl)-2-thiazolyl]benzamide (38). A solution of 4-nitrobenzoic acid (94 mg, $0.56 \mathrm{mmol}$ ) and PyBOP (440 mg, $0.84 \mathrm{mmol})$ and DIPEA (1.25 mL, $7.56 \mathrm{mmol})$ in $\mathrm{CH}_{2} \mathrm{Cl}_{2}(10 \mathrm{~mL})$ was stirred for 15 minutes and then 4-(pyridin-2-yl)thiazol-2-amine (100 $\mathrm{mg}, 0.56 \mathrm{mmol}$ ) was added. The reaction mixture was then stirred at room temperature and monitored by TLC analysis (EtOAc:hexane $=1: 1$ ) until completion. After $16 \mathrm{~h}$, the reaction mixture was poured to ice cooled water $(30 \mathrm{~mL})$ and extracted with $\mathrm{CH}_{2} \mathrm{Cl}_{2}(3 \times 50 \mathrm{~mL})$. The combined organic layer was dried over $\mathrm{Na}_{2} \mathrm{SO}_{4}$ and concentrated under reduced pressure. The crude was further purified via flash column chromatography on silica gel (100-200 mesh) using $2 \% \mathrm{CH}_{3} \mathrm{OH}$ in $\mathrm{CH}_{2} \mathrm{Cl}_{2}$ as eluent to afford 38 (30 mg, $16 \%$ yield), as a yellow solid; ${ }^{1} \mathrm{H}$ NMR: (300 MHz, DMSO-d $\left.\mathrm{d}_{6}\right): \delta 3.41(\mathrm{~s}, 3 \mathrm{H}), 7.35-7.39(\mathrm{~m}, 1 \mathrm{H}), 7.89-7.96(\mathrm{~m}, 2 \mathrm{H}), 8.02(\mathrm{~d}$, $J=7.7 \mathrm{~Hz}, 1 \mathrm{H}), 8.33-8.41(\mathrm{~m}, 4 \mathrm{H}), 8.63-8.64(\mathrm{~m}, 1 \mathrm{H}), 13.21(\mathrm{~s}, 1 \mathrm{H}) ; \mathrm{LCMS} \mathrm{m} / \mathrm{z}(\mathrm{M}+\mathrm{H})$ 327.09, purity: 96.6\%; HRMS MS ESI $m / z$ calcd for $\mathrm{C}_{15} \mathrm{H}_{10} \mathrm{~N}_{4} \mathrm{O}_{3} \mathrm{~S}(\mathrm{M}+\mathrm{H})^{+} 327.0546$, found $327.0525(\Delta 2.1 \mathrm{ppm})$.

2-Hydroxy- $\mathbf{N}$-(4-(pyridin-2-yl)thiazol-2-yl)benzamide (39). (i) To a mixture of salicylic acid $(1.30 \mathrm{~g}, 9.4 \mathrm{mmol})$ in acetic anhydride $(2.80 \mathrm{~g}, 28.3 \mathrm{mmol}) 3$ drops of phosphoric acid was added and stirred the mixture at $90^{\circ} \mathrm{C}$ for 5 minutes. Cooled the mixture and filtered the solid that formed and dried under vacuum to obtain 2 -acetoxybenzoic acid ( $1.20 \mathrm{~g}, 71 \%$ yield), as a white solid; ${ }^{1} \mathrm{H}$ NMR $\left(400 \mathrm{MHz}, \mathrm{CDCl}_{3}\right): \delta 8.12(\mathrm{~d}, J=7.6 \mathrm{~Hz}, 1 \mathrm{H}), 7.63(\mathrm{t}, J=7.6 \mathrm{~Hz}, 1 \mathrm{H})$, $7.36(\mathrm{t}, J=7.6 \mathrm{~Hz}, 1 \mathrm{H}), 7.14(\mathrm{~d}, J=8.0 \mathrm{~Hz}, 1 \mathrm{H}), 2.35(\mathrm{~s}, 3 \mathrm{H}) . \mathrm{MS} \mathrm{m} / \mathrm{z}(\mathrm{M}-\mathrm{H}) 179.05$

(ii) A solution of 2-acetoxybenzoic acid (200 $\mathrm{mg}, 1.13 \mathrm{mmol})$ and PyBOP $(810 \mathrm{mg}, 1.69$ mmol) and DIPEA $(0.58 \mathrm{~mL}, 3.3 \mathrm{mmol})$ in $\mathrm{CH}_{2} \mathrm{Cl}_{2}(10 \mathrm{~mL})$ was stirred for 15 minutes and then 4-(pyridin-2-yl)thiazol-2-amine 5 (200 $\mathrm{mg}, 1.13 \mathrm{mmol}$ ) was added. The reaction mixture was then stirred at room temperature for $16 \mathrm{~h}$. After TLC showed completion, the reaction 
mixture was diluted with $\mathrm{CH}_{2} \mathrm{Cl}_{2}(30 \mathrm{~mL})$ and washed with water $(2 \times 20 \mathrm{~mL})$. The organic layer was dried over $\mathrm{Na}_{2} \mathrm{SO}_{4}$ and concentrated. The resulting crude was purified by column chromatography on silica gel (100-200 mesh) using $2 \% \mathrm{CH}_{3} \mathrm{OH}$ in $\mathrm{CH}_{2} \mathrm{Cl}_{2}$ as eluent to afford the de-acetylated product 39 ( $13 \mathrm{mg}, 3 \%$ yield), as a white solid and de-acetylated product (40 mg, $12 \%$ yield); ${ }^{1} \mathrm{H}$ NMR: (300 MHz, DMSO-d $\left.\mathrm{d}_{6}\right): \delta 1.24-1.27(\mathrm{~m}, 1 \mathrm{H}), 7.00-7.09(\mathrm{~m}, 2 \mathrm{H}), 7.36$ $(\mathrm{m}, 1 \mathrm{H}), 7.48-7.53(\mathrm{~m}, 1 \mathrm{H}), 7.87-7.92(\mathrm{~m}, 2 \mathrm{H}), 8.01-8.04(\mathrm{~m}, 2 \mathrm{H}), 8.62-8.63(\mathrm{~m}, 1 \mathrm{H}), 11.76(\mathrm{~s}$, $1 \mathrm{H}), 12.06(\mathrm{~s}, 1 \mathrm{H}) ;{ }^{13} \mathrm{C}$ NMR: (300 MHz, DMSO-d 6 ): $\delta 112.7,117.6,119.9,120.7,123.4,130.8$, 135.0, 137.7, 149.9; LCMS m/z (M-H) 298.10, purity: 94.1\%; HRMS MS ESI $m / z$ calcd for $\mathrm{C}_{15} \mathrm{H}_{11} \mathrm{~N}_{3} \mathrm{O}_{2} \mathrm{~S}(\mathrm{M}+\mathrm{H})^{+} 298.06055$, found $298.0634(\Delta 2.8 \mathrm{ppm})$.

3,5-Dinitro- $\boldsymbol{N}$ - [4-(2-pyridinyl)-2-thiazolyl] benzamide (40). $25 \mathrm{mg}, 44 \%$ yield, as white solid; ${ }^{1} \mathrm{H}$ NMR: (300 MHz, DMSO-d $\left.\mathrm{d}_{6}\right): \delta 7.38-7.42(\mathrm{t}, J=6.3 \mathrm{~Hz}, 1 \mathrm{H}), 7.93-8.07(\mathrm{~m}, 3 \mathrm{H})$, 8.64-8.66 (m, 1H), $9.05(\mathrm{~s}, 2 \mathrm{H}), 9.33(\mathrm{~s}, 2 \mathrm{H}), 13.6(\mathrm{~s}, 1 \mathrm{H})$; HRMS MS ESI $m / z$ calcd for $\mathrm{C}_{15} \mathrm{H}_{9} \mathrm{~N}_{5} \mathrm{O}_{5} \mathrm{~S}(\mathrm{M}+\mathrm{H})^{+} 372.0397$, found $372.0379(\Delta 1.8 \mathrm{ppm})$.

$N$-Cyclopentyl- $N$ '- [4-(2-pyridinyl)-2-thiazolyl] urea (41). To 5 (18 mg, $0.1 \mathrm{mmol})$ dissolved in THF $(2 \mathrm{~mL})$ was added cyclopentyl isocyante $(0.011 \mathrm{~mL}, 0.1 \mathrm{mmol})$. The mixture was stirred at room temperature and the reaction was monitored via LC/MS. After $1 \mathrm{~h}$, the reaction mixture was evaporated and the resulting crude was recrystallized from ethanol to give 41 (4 $\mathrm{mg}, 13 \%$ yield), as a white solid; ${ }^{1} \mathrm{H}$ NMR: $\left(300 \mathrm{MHz}, \mathrm{DMSO}-\mathrm{d}_{6}\right): \delta 1.37-1.45(\mathrm{~m}, 2 \mathrm{H}), 1.52-$ $1.68(\mathrm{~m}, 4 \mathrm{H}), 1.82-1.90(\mathrm{~m}, 2 \mathrm{H}), 3.92-4.03(\mathrm{~m}, 2 \mathrm{H}), 6.60-6.62(\mathrm{~m}, 1 \mathrm{H}), 7.38-7.42(\mathrm{~m}, 1 \mathrm{H})$, $7.75(\mathrm{~s}, 1 \mathrm{H}), 7.97-7.98(\mathrm{~m}, 2 \mathrm{H}), 8.59-8.61(\mathrm{~m}, 1 \mathrm{H}), 10.34(\mathrm{~s}, 1 \mathrm{H})$; HRMS MS ESI $m / z$ calcd for $\mathrm{C}_{14} \mathrm{H}_{16} \mathrm{~N}_{4} \mathrm{OS}(\mathrm{M}+\mathrm{H})^{+} 289.1118$, found $289.1114(\Delta 0.4 \mathrm{ppm})$.

$N$-Phenyl- $N^{\prime}$ - [4-(2-pyridinyl)-2-thiazolyl]urea (42). To 5 (18 $\left.\mathrm{mg}, 0.1 \mathrm{mmol}\right)$ dissolved in THF $(2 \mathrm{~mL})$ was added phenyl isocyante $(0.018 \mathrm{~mL}, 0.1 \mathrm{mmol})$. The mixture was stirred at room temperature and the reaction was monitored via LC/MS. After $1 \mathrm{~h}$, the reaction mixture was evaporated and the resulting crude was recrystallized from ethanol to give $42(30 \mathrm{mg}$, $100 \%$ yield), as a white solid. ${ }^{1} \mathrm{H}$ NMR: $\left(300 \mathrm{MHz}, \mathrm{DMSO}-\mathrm{d}_{6}\right): \delta 7.03-7.08(\mathrm{t}, J=7.3 \mathrm{~Hz}, 1 \mathrm{H})$, 7.31-7.36 (t, $J=7.5 \mathrm{~Hz}, 2 \mathrm{H}), 7.40-7.50(\mathrm{~m}, 3 \mathrm{H}), 7.86(\mathrm{~s}, 1 \mathrm{H}), 7.98-8.05(\mathrm{~m}, 2 \mathrm{H}), 8.62-8.63(\mathrm{~m}$, $1 \mathrm{H}), 9.01(\mathrm{~s}, 1 \mathrm{H}), 10.75$ (br s, $1 \mathrm{H}) ;{ }^{13} \mathrm{C}$ NMR: (300 MHz, DMSO-d $\left.\mathrm{d}_{6}\right): \delta 113.2,119.1,121.4$, $123.3,123.8,129.3,138.8,140.0,148.0,152.0,160.0$; HRMS MS ESI $m / z$ calcd for $\mathrm{C}_{15} \mathrm{H}_{12} \mathrm{~N}_{4} \mathrm{OS}$ $(\mathrm{M}+\mathrm{H})+297.0805$, found $297.0790(\Delta 1.5 \mathrm{ppm})$.

General synthesis for compounds 43-61. Compounds 43-61 were prepared following the general protocol (procedure I) described for compounds 17-29 above.

4-Phenyl- $\mathrm{N}$ - [2-(trifluoromethyl)phenyl]-1,3-thiazol-2-amine (43). $43 \mathrm{mg}, 64 \%$ yield, as pink solid; ${ }^{1} \mathrm{H}$ NMR: $\left(300 \mathrm{MHz}, \mathrm{CDCl}_{3}\right): \delta 6.93(\mathrm{~s}, 1 \mathrm{H}), 7.16-7.21(\mathrm{t}, J=7.5 \mathrm{~Hz}, 1 \mathrm{H}), 7.33-7.47$ $(\mathrm{m}, 4 \mathrm{H}), 7.58-7.68(\mathrm{~m}, 2 \mathrm{H}), 7.88(\mathrm{~d}, J=7.1 \mathrm{~Hz}, 1 \mathrm{H}), 8.25(\mathrm{~d}, J=8.3 \mathrm{~Hz}, 1 \mathrm{H}) ;{ }^{13} \mathrm{C}$ NMR: $(300$ $\left.\mathrm{MHz}, \mathrm{CDCl}_{3}\right): \delta 103.2,120.3,122.7,126.1,126.6,126.7,128.0,128.6,133.2 ;$ HRMS MS ESI $m / z$ calcd for $\mathrm{C}_{16} \mathrm{H}_{11} \mathrm{~F}_{3} \mathrm{~N}_{2} \mathrm{~S}(\mathrm{M}+\mathrm{H})^{+} 321.0668$, found $321.0653(\Delta 1.5 \mathrm{ppm})$.

4-(Thiophen-2-yl)- $N$ - [2-(trifluoromethyl)phenyl]-1,3-thiazol-2-amine (44). $36 \mathrm{mg}$, $65 \%$ yield, as off-white solid; ${ }^{1} \mathrm{H}$ NMR: $\left(300 \mathrm{MHz}, \mathrm{CDCl}_{3}\right): \delta 6.79(\mathrm{~s}, 1 \mathrm{H}), 7.06-7.09(\mathrm{~m}, 1 \mathrm{H})$, $7.17-7.22(\mathrm{t}, J=7.6 \mathrm{~Hz}, 1 \mathrm{H}), 7.37-7.43(\mathrm{~m}, 2 \mathrm{H}), 7.57-7.67(\mathrm{~m}, 2 \mathrm{H}), 8.17(\mathrm{~d}, J=8.2 \mathrm{~Hz}, 1 \mathrm{H})$;

${ }^{13} \mathrm{C}$ NMR: $\left(300 \mathrm{MHz}, \mathrm{CDCl}_{3}\right.$ ): $\delta 101.8,120.6,123.0,123.9,125.0,126.6,126.70,126.78,126.8$, 127.6, 133.2, 133.3; HRMS MS ESI $m / z$ calcd for $\mathrm{C}_{14} \mathrm{H}_{9} \mathrm{~F}_{3} \mathrm{~N}_{2} \mathrm{~S}_{2}(\mathrm{M}+\mathrm{H})^{+} 327.0232$, found $327.0210(\Delta 2.2 \mathrm{ppm})$.

4-(Naphthalen-2-yl)- $\mathrm{N}$ - [2-(trifluoromethyl)phenyl]-1,3-thiazol-2-amine (45). $27 \mathrm{mg}$, $74 \%$ yield, as off-white solid; ${ }^{1} \mathrm{H}$ NMR: $\left(300 \mathrm{MHz}, \mathrm{CDCl}_{3}\right): \delta 7.04(\mathrm{~s}, 1 \mathrm{H}), 7.18-7.23(\mathrm{~m}, 1 \mathrm{H})$, 7.47-7.55 (m, 2H), 7.60-7.70 (m, 2H), $8.24(\mathrm{~d}, J=8.2 \mathrm{~Hz}, 1 \mathrm{H}), 8.41(\mathrm{~s}, 1 \mathrm{H}) ;{ }^{13} \mathrm{C}$ NMR: $(300$ $\left.\mathrm{MHz}, \mathrm{CDCl}_{3}\right): \delta 103.7,120.5,122.8,124.0,125.2,126.1,126.3,126.7,126.8,127.7,128.3,128.4$, $128.5,133.3$; HRMS MS ESI $m / z$ calcd for $\mathrm{C}_{20} \mathrm{H}_{13} \mathrm{~F}_{3} \mathrm{~N}_{2} \mathrm{~S}(\mathrm{M}+\mathrm{H})^{+} 371.0824$, found $371.0803(\Delta$ $2.1 \mathrm{ppm})$. 
4-(2-Methoxyphenyl)- $\mathrm{N}$ - [2-(trifluoromethyl)phenyl]-1,3-thiazol-2-amine (46). $30 \mathrm{mg}$, $70 \%$ yield, as white crystals; ${ }^{1} \mathrm{H}$ NMR: $\left(300 \mathrm{MHz}, \mathrm{CDCl}_{3}\right): \delta 3.98(\mathrm{~s}, 3 \mathrm{H}), 7.00(\mathrm{~d}, J=8.2 \mathrm{~Hz}$, $1 \mathrm{H}), 7.06-7.19\left(\mathrm{dt}, J_{1}=21.8 \mathrm{~Hz}, J_{2}=7.5 \mathrm{~Hz}, 2 \mathrm{H}\right), 7.28-7.35(\mathrm{~m}, 2 \mathrm{H}), 7.44(\mathrm{~s}, 1 \mathrm{H}), 7.57-7.66$ $(\mathrm{m}, 2 \mathrm{H}), 8.19-8.22\left(\mathrm{dd}, J_{1}=7.7 \mathrm{~Hz}, J_{2}=1.5 \mathrm{~Hz}, 1 \mathrm{H}\right), 8.27(\mathrm{~d}, J=8.3 \mathrm{~Hz}, 1 \mathrm{H}) ;{ }^{13} \mathrm{C}$ NMR: $(300$ $\left.\mathrm{MHz}, \mathrm{CDCl}_{3}\right): \delta 55.4,108.1,111.0,120.0,120.8,122.3,126.5,126.6,128.7,130.0,133.2,147.3$, $156.9,161.4$; HRMS MS ESI $m / z$ calcd for $\mathrm{C}_{17} \mathrm{H}_{13} \mathrm{~F}_{3} \mathrm{~N}_{2} \mathrm{OS}(\mathrm{M}+\mathrm{H})^{+} 351.0773$, found 351.0752 $(\Delta 2.1 \mathrm{ppm})$.

2-(2- [2-(Trifluoromethyl)phenyl] amino-1,3-thiazol-4-yl)phenol (47). $37 \mathrm{mg}, 67 \%$ yield, as white crystals; ${ }^{1} \mathrm{H}$ NMR: $\left(300 \mathrm{MHz}, \mathrm{CDCl}_{3}\right): \delta 6.87-6.92(\mathrm{~m}, 2 \mathrm{H}), 6.98-7.01(\mathrm{~m}, 1 \mathrm{H})$, 7.22-7.25 (m, 1H), 7.30-7.32 (m, 1H), 7.57-7.71 (m, 3H), $7.90(\mathrm{~d}, J=8.2 \mathrm{~Hz}, 1 \mathrm{H}), 11.2(\mathrm{br} \mathrm{s}$, $1 \mathrm{H}) ;{ }^{13} \mathrm{C}$ NMR: $\left(300 \mathrm{MHz}, \mathrm{CDCl}_{3}\right): \delta 101.7,117.4,117.7,119.4,121.9,124.2,125.8,126.8$, $126.9,127.01,127.08,130.0,133.3,155.7$; HRMS MS ESI $m / z$ calcd for $\mathrm{C}_{16} \mathrm{H}_{11} \mathrm{~F}_{3} \mathrm{~N}_{2} \mathrm{OS}(\mathrm{M}+\mathrm{H})^{+}$ 337.0617 , found $337.0592(\Delta 2.5 \mathrm{ppm})$.

4- [(3R,5S,7s)-Adamantan-1-yl]-N- [2-(trifluoromethyl)phenyl]-1,3-thiazol-2-amine (48). $53 \mathrm{mg}, 73 \%$ yield, as white crystals; ${ }^{1} \mathrm{H}$ NMR: $\left(300 \mathrm{MHz}, \mathrm{CDCl}_{3}\right): \delta 1.79(\mathrm{~s}, 6 \mathrm{H}), 1.98$ (s, $6 \mathrm{H}), 2.10(\mathrm{br} \mathrm{s}, 3 \mathrm{H}), 6.27(\mathrm{~s}, 1 \mathrm{H}), 7.09-7.14(\mathrm{t}, J=7.5 \mathrm{~Hz}, 1 \mathrm{H}), 7.52-7.57(\mathrm{t}, J=8.0 \mathrm{~Hz}, 1 \mathrm{H})$, $7.60(\mathrm{~d}, J=7.8 \mathrm{~Hz}, 1 \mathrm{H}), 8.17(\mathrm{~d}, J=8.2 \mathrm{~Hz}, 1 \mathrm{H}) ;{ }^{13} \mathrm{C} \mathrm{NMR}:\left(300 \mathrm{MHz}, \mathrm{CDCl}_{3}\right): \delta 28.5,36.8$, $41.8,100.8,119.7,122.0,126.5,126.6,133.1$; HRMS MS ESI $m / z$ calcd for $\mathrm{C}_{20} \mathrm{H}_{21} \mathrm{~F}_{3} \mathrm{~N}_{2} \mathrm{~S}$ $(\mathrm{M}+\mathrm{H})^{+} 379.145$, found $379.1430(\Delta 0.2 \mathrm{ppm})$.

$\mathrm{N}$-(2,6-Dimethylphenyl)-4-phenyl-1,3-thiazol-2-amine (49). $40 \mathrm{mg}, 81 \%$ yield, as white solid; ${ }^{1} \mathrm{H}$ NMR: $\left(300 \mathrm{MHz}, \mathrm{CDCl}_{3}\right): \delta 2.35(\mathrm{~s}, 6 \mathrm{H}), 6.63(\mathrm{~s}, 1 \mathrm{H}), 7.15-7.20(\mathrm{~m}, 6 \mathrm{H}), 7.64-7.67$ (m, 2H), 8.64 (br s, $1 \mathrm{H}) ;{ }^{13} \mathrm{C} \mathrm{NMR:} \mathrm{(300} \mathrm{MHz,} \mathrm{CDCl}_{3}$ ): $\delta 18.2,101.2,125.9,127.5,127.9,128.3$, $128.8,134.7,137.2,137.7,151.7,170.9$; HRMS MS ESI $m / z$ calcd for $\mathrm{C}_{14} \mathrm{H}_{11} \mathrm{~N}_{3} \mathrm{~S}(\mathrm{M}+\mathrm{H})^{+}$ 281.1107, found $281.1091(\Delta 1.6 \mathrm{ppm})$.

$\mathrm{N}$-(2,6-Dimethylphenyl)-4-(thiophen-2-yl)-1,3-thiazol-2-amine (50). $46 \mathrm{mg}, 83 \%$ yield, as white solid; ${ }^{1} \mathrm{H}$ NMR: $\left(300 \mathrm{MHz}, \mathrm{CDCl}_{3}\right): \delta 2.34(\mathrm{~s}, 6 \mathrm{H}), 6.54(\mathrm{~s}, 1 \mathrm{H}), 6.91-6.94(\mathrm{t}, J=4.9$ $\mathrm{Hz}, 1 \mathrm{H}), 7-14-7.24$ (m, 5H), 7.89 (br s, $1 \mathrm{H}) ;{ }^{13} \mathrm{C} \mathrm{NMR:} \mathrm{(300} \mathrm{MHz,} \mathrm{CDCl}_{3}$ ): $\delta$ 18.2, 100.3, 123.4, $124.3,127.4,128.1,128.9,137.2,137.4,138.6,146.0,170.5$; HRMS MS ESI $m / z$ calcd for $\mathrm{C}_{15} \mathrm{H}_{14} \mathrm{~N}_{2} \mathrm{~S}_{2}(\mathrm{M}+\mathrm{H})^{+}$287.0671, found $287.0655(\Delta 1.6 \mathrm{ppm})$.

$\mathrm{N}$-(2,6-Dimethylphenyl)-4-(pyridin-3-yl)-1,3-thiazol-2-amine (51). $34 \mathrm{mg}, 40 \%$ yield, as off-white solid; ${ }^{1} \mathrm{H}$ NMR: $\left(300 \mathrm{MHz}, \mathrm{CDCl}_{3}\right)$ : $\delta 2.34(\mathrm{~s}, 5 \mathrm{H}), 6.73(\mathrm{~s}, 1 \mathrm{H}), 7.92-7.94(\mathrm{~m}, 1 \mathrm{H})$, $8.44(\mathrm{~d}, J=42.6 \mathrm{~Hz}, 2 \mathrm{H}), 9.10(\mathrm{~s}, 1 \mathrm{H}) ;{ }^{13} \mathrm{C}$ NMR: $\left(300 \mathrm{MHz}, \mathrm{CDCl}_{3}\right): \delta 18.1,102.6,123.1,128.0$, $128.9,133.1,137.0,147.4,148.3,171.1 ;$ LCMS m/z $(\mathrm{M}+\mathrm{H})$ 283.08, purity 99.81\%; HRMS MS ESI $m / z$ calcd for $\mathrm{C}_{16} \mathrm{H}_{15} \mathrm{~N}_{3} \mathrm{~S}(\mathrm{M}+\mathrm{H})^{+} 282.1059$, found $282.1045(\Delta 1.4 \mathrm{ppm})$.

$\mathrm{N}$-(2,6-Dimethylphenyl)-4-(pyrazin-2-yl)thiazol-2-amine (52). To a solution of 1-(pyrazin-2-yl)ethan-1-one ( $250 \mathrm{mg}, 2.03 \mathrm{mmol})$ in $\mathrm{AcOH}(5 \mathrm{~mL})$, pyridinium bromide perbromide (780 mg, $2.4 \mathrm{mmol}$ ) was added and allowed the mixture to stir at room temperature for 48 hours. After TLC showed completion, diluted the mixture with EtOAc $(20 \mathrm{~mL})$ and washed with water $(3 \times 10 \mathrm{~mL})$. The organic layer was dried over $\mathrm{Na}_{2} \mathrm{SO}_{4}$ and concentrated to obtain crude 2-bromo-1-(pyrazin-2-yl)ethan-1-one, which was used in next step without further purification (300 mg, crude). To a solution of 1-(2,6-dimethylphenyl)thiourea (134 mg, $0.7 \mathrm{mmol}$ ) in DMF (5 mL), crude 2-bromo-1-(pyrazin-2-yl)ethan-1-one (300 mg, $0.7 \mathrm{mmol}$ ) and triethylamine $(0.31 \mathrm{~mL}, 2.2 \mathrm{mmol})$ were added successively and heated the mixture at $70^{\circ} \mathrm{C}$ for 2 hours. After TLC showed completion, reaction mixture was diluted with EtOAc $(20 \mathrm{~mL})$ and washed with water $(3 \times 10 \mathrm{~mL})$. The organic layer was dried over $\mathrm{Na}_{2} \mathrm{SO}_{4}$ and concentrated. The resulting residue was purified by column chromatography (silicagel, 100-200\#) and the desired product was eluted with $20 \% \mathrm{EtOAc}$ in hexane. Concentration of the pure fractions afforded 52 (135 mg, 32\% yield), as a pale yellow solid; ${ }^{1} \mathrm{H}$ NMR: (400 MHz, DMSO-d $\left.{ }_{6}\right): \delta 2.23$ (s, 6H), 7.14-7.20 (m, 3H), $7.45(\mathrm{~s}, 1 \mathrm{H}), 8.54(\mathrm{~d}, J=2.4 \mathrm{~Hz}, 1 \mathrm{H}), 8.61(\mathrm{t}, J=1.6 \mathrm{~Hz}, 1 \mathrm{H}), 8.99$ 
(d, $J=1.6 \mathrm{~Hz}, 1 \mathrm{H}), 9.43(1 \mathrm{H}, \mathrm{s}) ;{ }^{13} \mathrm{C}$ NMR: $\left(300 \mathrm{MHz}, \mathrm{CDCl}_{3}\right) \delta 18.1,107.7,128.1,128.9,137.0$, 137.4, 142.5, 142.7, 143.8, 148.3, 148.8, 171.0; LCMS m/z (M+H) 283.08, purity 99.8\%; HRMS MS ESI $m / z$ calcd for $\mathrm{C}_{15} \mathrm{H}_{14} \mathrm{~N}_{4} \mathrm{~S}(\mathrm{M}+\mathrm{H})^{+} 283.1012$, found $283.1001(\Delta 1.1 \mathrm{ppm})$.

$\mathrm{N}$-(2,6-Dimethylphenyl)-4-(pyrimidin-4-yl)thiazol-2-amine (53). (i) To a suspension of 4-methylpyrimidine $(5.0 \mathrm{~g}, 0.053 \mathrm{~mol})$ in water $(300 \mathrm{~mL}), \mathrm{KMNO}_{4}(21 \mathrm{~g}, 0.132 \mathrm{~mol})$ and $\mathrm{KOH}$ $(20.8 \mathrm{~g}, 0.372 \mathrm{~mol})$ were added and heated the mixture at $75^{\circ} \mathrm{C}$ for 1.5 hours. Cooled to room temperature and ethanol $(300 \mathrm{~mL})$ was added drop wise. Filtered off the solids over Celite and concentrated the filtrate. The resulting crude was diluted with water $(50 \mathrm{~mL})$ and acidified with conc. HCl. Precipitate was collected and dried under vacuum to obtain pyrimidine-4-carboxylic acid (4.5 g, 67\% yield), as a white solid. ${ }^{1} \mathrm{H}$ NMR (400 MHz, DMSO-d $\left.{ }_{6}\right): \delta 13.93$ (brs, $\left.1 \mathrm{H}\right)$, $9.37(\mathrm{~d}, J=1.2 \mathrm{HZ}, 1 \mathrm{H}), 9.06(\mathrm{~d}, J=4.8 \mathrm{~Hz}, 1 \mathrm{H}), 8.01(\mathrm{dd}, J=4.8,1.2 \mathrm{~Hz}, 1 \mathrm{H})$.

(ii) To a solution of pyrimidine-4-carboxylic acid $(2.0 \mathrm{~g}, 16.0 \mathrm{mmol})$ in THF $(25 \mathrm{~mL})$, EDC. $\mathrm{HCl}(3.1 \mathrm{~g}, 16.5 \mathrm{mmol}), \mathrm{HOBt}(1.5 \mathrm{~g}, 10 \mathrm{mmol})$ and DIPEA $(2.5 \mathrm{~mL}, 13.7 \mathrm{mmol})$ were sequentially added. After stirring this mixture for 1 hour under $\mathrm{N}_{2}$ atmosphere, $\mathrm{N}, \mathrm{O}$-dimethylhydroxylamine hydrochloride $(1.57 \mathrm{~g}, 16.0 \mathrm{mmol})$ was added continued stirring for $16 \mathrm{~h}$. After completion, distilled off the solvent and diluted the residue with water $(50 \mathrm{~mL})$. The aqueous layer was extracted with EtOAc $(3 \times 100 \mathrm{~mL})$, the combined organic layer was dried over anhydrous $\mathrm{Na}_{2} \mathrm{SO}_{4}$ and concentrated under reduced pressure. The crude was further purified by column chromatography on silica gel (100-200 \#) using 25\% EtOAc in hexane as eluent to afford $N$-methoxy- $N$-methylpyrimidine-4-carboxamide (2.4 g, 89\% yield), as a viscous liquid.

(iii) To a solution of $N$-methoxy- $N$-methylpyrimidine-4-carboxamide $(2.25 \mathrm{~g}, 13.4 \mathrm{mmol})$ in dry THF $(15 \mathrm{~mL})$ at $-55^{\circ} \mathrm{C}$ under nitrogen atmosphere, methyl magnesium bromide (5.4 $\mathrm{mL}, 3 \mathrm{M}$ solution, $16.1 \mathrm{mmol}$ ) was added drop wise and allowed the reaction to reach room temperature. After TLC showed completion, quenched the reaction with saturated ammonium chloride solution $(10 \mathrm{~mL})$ and extracted with EtOAc $(3 \times 25 \mathrm{~mL})$. The combined organic layer was dried over anhydrous $\mathrm{Na}_{2} \mathrm{SO}_{4}$ and concentrated under reduced pressure. The crude was purified by column chromatography on silica gel (100-200 \#) using 5\% EtOAc in hexane as eluent to afford 1-(pyrimidin-4-yl)ethan-1-one (225 mg, 14\% yield), as a white solid ${ }^{1} \mathrm{H}$ NMR (400 MHz, DMSO-d 6 ): $\delta 9.42(\mathrm{~s}, 1 \mathrm{H}), 9.09(\mathrm{~d}, J=4.8 \mathrm{~Hz}, 1 \mathrm{H}), 7.90(\mathrm{dd}, \mathrm{J}=5.2,1.2 \mathrm{~Hz}, 1 \mathrm{H})$, $2.65(\mathrm{~s}, 3 \mathrm{H})$.

(iv) To a solution of 1-(pyrimidin-4-yl)ethan-1-one (0.30 g, $2.4 \mathrm{mmol})$ in $\mathrm{AcOH}(10 \mathrm{~mL})$, pyridinium bromide perbromide $(0.94 \mathrm{~g}, 2.9 \mathrm{mmol})$ was added and allowed the mixture to stir at room temperature for 48 hours. After TLC showed completion, diluted the mixture with EtOAc $(30 \mathrm{~mL})$ and washed with water $(3 \times 20 \mathrm{~mL})$. The organic layer was dried over $\mathrm{Na}_{2} \mathrm{SO}_{4}$ and concentrated to obtain crude 2-bromo-1-(pyrazin-2-yl)ethan-1-one (510 mg, crude), which was used in next step without further purification.

(v) To a solution of 1-(2,6-dimethylphenyl)thiourea (179 mg, $0.99 \mathrm{mmol})$ in DMF (10 mL), 2-bromo-1-(pyrimidin-4-yl)ethan-1-one $(200 \mathrm{mg}, 0.99 \mathrm{mmol})$ and triethylamine $(0.4 \mathrm{~mL}, 3$ $\mathrm{mmol}$ ) were added successively and heated the mixture at $70^{\circ} \mathrm{C}$ for 2 hours. After TLC showed completion, reaction mixture was diluted with EtOAc $(30 \mathrm{~mL})$ and washed with water $(3 \times 10$ $\mathrm{mL}$ ). The organic layer was dried over $\mathrm{Na}_{2} \mathrm{SO}_{4}$ and concentrated. The resulting residue was purified by column chromatography (silicagel, 100-200\#) and the desired product was eluted with 25\% EtOAc in hexane. Concentration of the pure fractions afforded $\mathbf{5 3}(110 \mathrm{mg}, 39 \%$ yield), as a pale yellow solid; ${ }^{1} \mathrm{H}$ NMR: $\left(300 \mathrm{MHz}, \mathrm{CDCl}_{3}\right): \delta 2.34(\mathrm{~s}, 6 \mathrm{H}), 7.17-7.23(\mathrm{~m}, 3 \mathrm{H})$, $7.48(\mathrm{~s}, 1 \mathrm{H}), 7.63-7.64(\mathrm{~m}, 1 \mathrm{H}), 8.18(\mathrm{br} \mathrm{s}, 1 \mathrm{H}), 8.54-8.56(\mathrm{~m}, 1 \mathrm{H}), 9.00(\mathrm{br} \mathrm{s}, 1 \mathrm{H}) ;{ }^{13} \mathrm{C} \mathrm{NMR}$ : (300 MHz, $\left.\mathrm{CDCl}_{3}\right): \delta 18.1,110.2,116.8,128.3,129.0,137.0,157.5,158.7 ; \mathrm{LCMS} \mathrm{m} / \mathrm{z}(\mathrm{M}+\mathrm{H})$ 283.08, purity 99.8\%; HRMS MS ESI $m / z$ calcd for $\mathrm{C}_{15} \mathrm{H}_{14} \mathrm{~N}_{4} \mathrm{~S}(\mathrm{M}+\mathrm{H})^{+} 283.1012$, found $283.1001(\Delta 1.1 \mathrm{ppm})$. 
$\mathrm{N}$-(2,6-Dimethylphenyl)-4-(1H-pyrazol-3-yl)thiazol-2-amine (54). To a solution of 1(2,6-dimethylphenyl)thiourea $(0.666 \mathrm{~g}, 3.70 \mathrm{mmol})$ in DMF $(10 \mathrm{~mL}), 2$-bromo-1-(1H-pyrazol3-yl)ethan-1-one $(0.70 \mathrm{~g}, 3.70 \mathrm{mmol})$ and triethylamine $(1 \mathrm{~mL}, 7.40 \mathrm{mmol})$ were added successively and heated the mixture at $70^{\circ} \mathrm{C}$ for 2 hours. After TLC showed completion, the reaction mixture was diluted with EtOAc $(30 \mathrm{~mL})$ and washed with water $(3 \times 10 \mathrm{~mL})$. The organic layer was dried over $\mathrm{Na}_{2} \mathrm{SO}_{4}$ and concentrated. The resulting residue was purified by column chromatography (silicagel, 100-200\#) and the desired product was eluted with 50\% EtOAc in hexane. Concentration of the pure fractions afforded $\mathbf{5 4}(215 \mathrm{mg}, 21 \%$ yield), as an off-white solid; ${ }^{1}$ H NMR: (300 MHz, DMSO- $\left.\mathrm{d}_{6}\right): \delta 2.22(\mathrm{~s}, 6 \mathrm{H}), 6.44(\mathrm{~s}, 1 \mathrm{H}), 6.83(\mathrm{~m}, 1 \mathrm{H}), 7.15(\mathrm{~s}, 3 \mathrm{H})$, 7.47-7.69 (m, $1 \mathrm{H}), 9.21(\mathrm{~s}, 1 \mathrm{H})$; LCMS m/z $(\mathrm{M}+\mathrm{H})$ 271.11, purity: 97.9\%; HRMS MS ESI $m / z$ calcd for $\mathrm{C}_{14} \mathrm{H}_{14} \mathrm{~N}_{4} \mathrm{~S}(\mathrm{M}+\mathrm{H})^{+} 271.1012$, found $271.0998(\Delta 1.4 \mathrm{ppm})$.

$\mathrm{N}$-(4-Phenyl-1,3-thiazol-2-yl)pyridin-2-amine (55). To 4-phenyl-2-thiazolamine (50 $\mathrm{mg}$, $0.3 \mathrm{mmol})$ dissolved in DMF $(2 \mathrm{~mL})$ was added $\mathrm{K}_{2} \mathrm{CO}_{3}(78 \mathrm{mg}, 0.6 \mathrm{mmol})$, followed by the addition of 2-chloropyridine $(0.02 \mathrm{~mL}, 0.3 \mathrm{mmol})$. The mixture was stirred at $90^{\circ} \mathrm{C}$ and the reaction was monitored via LC/MS. After $16 \mathrm{~h}$, the reaction was cooled to room temperature, diluted with water and extracted with EtOAc $(3 \times 25 \mathrm{~mL})$. The combined organic layers were washed with brine $(5 \times 25 \mathrm{~mL})$, collected, dried over $\mathrm{Na}_{2} \mathrm{SO}_{4}$ and concentrated in vacuo. The resulting crude was purified via flash column chromatography to give $\mathbf{5 5}$ (40 $\mathrm{mg}, 81 \%$ yield), as an white solid. ${ }^{1} \mathrm{H}$ NMR: $\left(300 \mathrm{MHz}, \mathrm{CDCl}_{3}\right): \delta 6.31(\mathrm{~d}, J=8.3 \mathrm{~Hz}, 1 \mathrm{~Hz}), 6.76-6.80(\mathrm{t}, J=6.6$ $\mathrm{Hz}, 1 \mathrm{H}), 7.10(\mathrm{~s}, 1 \mathrm{H}), 7.22-7.32(\mathrm{~m}, 2 \mathrm{H}), 7.36-7.41(\mathrm{t}, J=7.6 \mathrm{~Hz}, 2 \mathrm{H}), 7.94(\mathrm{~d}, J=7.2 \mathrm{~Hz}, 2 \mathrm{H})$, 8.33-8.34 (m, 1H), $11.2(\mathrm{~s}, 1 \mathrm{H}) ;{ }^{13} \mathrm{C}$ NMR: $\left(300 \mathrm{MHz}, \mathrm{CDCl}_{3}\right): \delta$ 105.7, 110.8, 116.1, 126.2, $127.8,128.7,134.8,137.2,146.4,149.3,151.4,161.7$; HRMS MS ESI $m / z$ calcd for $\mathrm{C}_{14} \mathrm{H}_{15} \mathrm{~F}_{3} \mathrm{~N}_{2} \mathrm{~S}$ $(\mathrm{M}+\mathrm{H})^{+} 254.0746$, found $254.0731(\Delta 1.5 \mathrm{ppm})$.

$\mathrm{N}$ - [4-(Thiophen-2-yl)-1,3-thiazol-2-yl]pyridin-2-amine (56). To 4-(2-thienyl)-2-thiazolamine $(50 \mathrm{mg}, 0.3 \mathrm{mmol})$ dissolved in $\mathrm{DMF}(2 \mathrm{~mL})$ was added $\mathrm{K}_{2} \mathrm{CO}_{3}(78 \mathrm{mg}, 0.6 \mathrm{mmol})$, followed by the addition of 2-chloropyridine $(0.02 \mathrm{~mL}, 0.3 \mathrm{mmol})$. The mixture was stirred at $90^{\circ} \mathrm{C}$ and the reaction was monitored via LC/MS. After $16 \mathrm{~h}$, the reaction was cooled to room temperature, diluted with water and extracted with EtOAc $(3 \times 25 \mathrm{~mL})$. The combined organic layers were washed with brine $(5 \times 25 \mathrm{~mL})$, collected, dried over $\mathrm{Na}_{2} \mathrm{SO}_{4}$ and concentrated in vacuo. The resulting crude was purified via flash column chromatography to give $\mathbf{5 6}$ (48) $\mathrm{mg}$, 98\% yield), as an off-white solid. ${ }^{1} \mathrm{H}$ NMR: $\left(300 \mathrm{MHz}, \mathrm{CDCl}_{3}\right): \delta 6.46(\mathrm{~d}, J=8.2 \mathrm{~Hz}, 1 \mathrm{H}), 6.80-$ $6.84(\mathrm{t}, J=6.3 \mathrm{~Hz}, 1 \mathrm{H}), 6.97-7.03(\mathrm{~m}, 2 \mathrm{H}), 7.21(\mathrm{~d}, J=4.9 \mathrm{~Hz}, 1 \mathrm{H}), 7.34-7.39(\mathrm{t}, J=7.4 \mathrm{~Hz}$, $1 \mathrm{H}), 7.45-7.46(\mathrm{~m}, 1 \mathrm{H}), 8.34-8.35(\mathrm{~m}, 1 \mathrm{H}), 11.0(\mathrm{br} \mathrm{s}, 1 \mathrm{H}) ;{ }^{13} \mathrm{C} \mathrm{NMR}:\left(300 \mathrm{MHz}, \mathrm{CDCl}_{3}\right): \delta$ $104.9,110.8,116.2,123.9,124.8,127.7,137.4,138.7,143.7,146.4,151.3,161.5$; HRMS MS ESI $m / z$ calcd for $\mathrm{C}_{12} \mathrm{H}_{9} \mathrm{~N}_{3} \mathrm{~S}_{2}(\mathrm{M}+\mathrm{H})^{+} 260.0311$, found $260.0289(\Delta 2.2 \mathrm{ppm})$.

$\mathrm{N}$-(Pyridin-2-yl)-2,4'-bithiazol-2'-amine (57). (i) To a solution of 1-(thiazol-2-yl)ethan1-one $(0.25 \mathrm{~g}, 1.97 \mathrm{mmol})$ in $\mathrm{AcOH}(5 \mathrm{~mL})$, pyridinium bromide perbromide $(0.82 \mathrm{~g}, 2.57$ $\mathrm{mmol}$ ) was added and allowed the mixture to stir at room temperature for 35 hours. After TLC showed completion, diluted the mixture with EtOAc $(20 \mathrm{~mL})$ and washed with water $(3 \times 10$ $\mathrm{mL}$ ). The organic layer was dried over $\mathrm{Na}_{2} \mathrm{SO}_{4}$ and concentrated to obtain crude 2-bromo-1(thiazol-2-yl)ethan-1-one (310 mg, crude), which was used in next step without further purification.

(ii) To a solution of 1-(pyridin-2-yl)thiourea $(0.123 \mathrm{~g}, 0.8 \mathrm{mmol})$ in DMF $(7 \mathrm{~mL}), 2$-bromo1-(thiazol-2-yl)ethan-1-one $(0.15 \mathrm{~g}, 0.73 \mathrm{mmol})$ and triethylamine $(0.2 \mathrm{~mL}, 1.46 \mathrm{mmol})$ were added successively and heated the mixture at $70^{\circ} \mathrm{C}$ for 2 hours. After TLC showed completion, reaction mixture was diluted with EtOAc $(20 \mathrm{~mL})$ and washed with water $(3 \times 10 \mathrm{~mL})$. The organic layer was dried over $\mathrm{Na}_{2} \mathrm{SO}_{4}$ and concentrated. The resulting residue was purified by column chromatography (silicagel, 100-200\#) and the desired product was eluted with $40 \%$ EtOAc in hexane. Concentration of the pure fractions afforded $\mathbf{5 7}$ (183 mg, 96\% yield), as off- 
white solid; ${ }^{1} \mathrm{H}$ NMR: $\left(300 \mathrm{MHz}, \mathrm{CDCl}_{3}\right): \delta 6.67(\mathrm{~d}, J=8.2 \mathrm{~Hz}, 1 \mathrm{H}), 6.87-6.91(\mathrm{~m}, 1 \mathrm{H}), 7.49-$ $7.56(\mathrm{~m}, 2 \mathrm{H}), 7.84-7.85(\mathrm{~m}, 1 \mathrm{H}), 8.36-8.38(\mathrm{~m}, 1 \mathrm{H}), 9.91$ (br s, $1 \mathrm{H}) ;{ }^{13} \mathrm{C}$ NMR: $(300 \mathrm{MHz}$, $\left.\mathrm{CDCl}_{3}\right): \delta 109.2,110.6,116.6,118.9,137.8,143.4,143.6,146.7,151.0,161.0,163.3 ; \mathrm{LCMS} \mathrm{m} / \mathrm{z}$ $(\mathrm{M}+\mathrm{H})$ 261.02, purity 99.0\%; HRMS MS ESI $m / z$ calcd for $\mathrm{C}_{11} \mathrm{H}_{8} \mathrm{~N}_{4} \mathrm{~S}_{2}(\mathrm{M}+\mathrm{H})^{+} 261.0263$, found $261.0250(\Delta 1.3 \mathrm{ppm})$.

4-(Pyrazin-2-yl)- $\mathrm{N}$-(pyridin-2-yl)thiazol-2-amine (58). To a solution of 1-(pyridin-2-yl) thiourea $(0.129 \mathrm{~g}, 0.85 \mathrm{mmol})$ in DMF $(7 \mathrm{~mL}), 2$-bromo-1-(pyrazin-2-yl)ethan-1-one ( $0.20 \mathrm{~g}$, $0.99 \mathrm{mmol})$ and triethylamine $(0.3 \mathrm{~mL}, 2.0 \mathrm{mmol})$ were added successively and heated the mixture at $70^{\circ} \mathrm{C}$ for 2 hours. After TLC showed completion, reaction mixture was diluted with EtOAc $(20 \mathrm{~mL})$ and washed with water $(3 \times 10 \mathrm{~mL})$. The organic layer was dried over $\mathrm{Na}_{2} \mathrm{SO}_{4}$ and concentrated. The resulting residue was purified by column chromatography (silicagel, $100-200 \#)$ and the desired product was eluted with $3 \% \mathrm{CH}_{3} \mathrm{OH}$ in $\mathrm{CH}_{2} \mathrm{Cl}_{2}$. Concentration of the pure fractions afforded 58 ( $35 \mathrm{mg}, 13.8 \%$ yield), as a greenish solid; ${ }^{1} \mathrm{H}$ NMR: (400 MHz, DMSO- $\left.\mathrm{d}_{6}\right): \delta 6.95(\mathrm{~d}, J=4.8 \mathrm{~Hz}, 1 \mathrm{H}), 7.11(\mathrm{~d}, J=8.4 \mathrm{~Hz}, 1 \mathrm{H}), 7.71-7.76(\mathrm{~m}, 1 \mathrm{H}), 7.79(\mathrm{~s}, 1 \mathrm{H})$, $8.32-8.33(\mathrm{~m}, 1 \mathrm{H}), 8.58(\mathrm{~d}, J=2.4 \mathrm{~Hz}, 1 \mathrm{H}), 8.65-8.66(\mathrm{~m}, 1 \mathrm{H}), 9.16(\mathrm{~d}, J=1.6 \mathrm{~Hz}, 1 \mathrm{H}), 11.57$ (s, 1H); ${ }^{13} \mathrm{C}$ NMR: (300 MHz, DMSO-d $\left.{ }_{6}\right): 111.3,114.5,116.8,117.0,138.6,146.8,147.2,152.0$, 158.8, 158.9, 159.0, 160.7; LCMS m/z (M+H) 256.04, purity 98.9\%; HRMS MS ESI $m / z$ calcd for $\mathrm{C}_{12} \mathrm{H}_{9} \mathrm{~N}_{5} \mathrm{~S}(\mathrm{M}+\mathrm{H})^{+} 256.06122$, found $256.0634(\Delta 2.2 \mathrm{ppm})$.

4-(1H-Pyrazol-3-yl)- $\mathrm{N}$-(pyridin-2-yl)thiazol-2-amine (59). (i) To a suspension of 3-methyl-1H-pyrazole $(4.0 \mathrm{~g}, 0.048 \mathrm{~mol})$ in water $(100 \mathrm{~mL}), \mathrm{KMNO}_{4}(19.24 \mathrm{~g}, 0.121 \mathrm{~mol})$ was added and heated the mixture at $100^{\circ} \mathrm{C}$ for 4 hours. Cooled to room temperature and filtered off the solids over celite bed and concentrated the filtrate to $30 \mathrm{~mL}$. The concentrated filtrate was with conc. $\mathrm{HCl}$. The precipitate was collected and dried under vacuum to obtain $1 \mathrm{H}$-pyrazole-3-carboxylic acid (2.5 g, 46\% yield), as a white solid; ${ }^{1} \mathrm{H}$ NMR (400 MHz, DMSO- $\left.\mathrm{d}_{6}\right): \delta$ $6.71(\mathrm{~s}, 1 \mathrm{H}), 7.75(\mathrm{~s}, 1 \mathrm{H}), 12.61$ (brs, $1 \mathrm{H})$.

(ii) To a solution of $1 \mathrm{H}$-pyrazole-3-carboxylic acid $(2.5 \mathrm{~g}, 22.3 \mathrm{mmol})$ and $\mathrm{N}, \mathrm{O}$-dimethylhydroxylamine hydrochloride ( $2.10 \mathrm{~g}, 22.3 \mathrm{mmol})$ in $\mathrm{CH}_{2} \mathrm{Cl}_{2}(25 \mathrm{~mL})$, EDCI.HCl $(8.9 \mathrm{~g}, 46.6$ $\mathrm{mmol}), \mathrm{HOBt}(7.8 \mathrm{~g}, 58.2 \mathrm{mmol}$ ) and DIPEA $(15 \mathrm{~g}, 113.7 \mathrm{mmol})$ were sequentially added and stirred at room temperature for $16 \mathrm{~h}$. After completion, distilled off the solvent and the crude was purified by column chromatography on silica gel (100-200 \#) using $80 \%$ EtOAc in hexane as eluent to afford $\mathrm{N}$-methoxy- $\mathrm{N}$-methyl- $1 \mathrm{H}$-pyrazole-3-carboxamide (3.4 g, 59\% yield), as an off-white solid; ${ }^{1} \mathrm{H}$ NMR $\left(400 \mathrm{MHz}, \mathrm{CDCl}_{3}\right.$ ): $\delta 3.39$ (s, $\left.3 \mathrm{H}\right), 3.78(\mathrm{~s}, 3 \mathrm{H}), 6.83(\mathrm{~d}, J=1.2 \mathrm{~Hz}$, $1 \mathrm{H}), 7.66(\mathrm{~d}, J=1.2 \mathrm{~Hz}, 1 \mathrm{H})$.

(iii) To a solution of $N$-methoxy- $N$-methyl- $1 H$-pyrazole-3-carboxamide $(2.0 \mathrm{~g}, 12.9 \mathrm{mmol})$ and catalytic amount of DMAP in $\mathrm{CH}_{2} \mathrm{Cl}_{2}(20 \mathrm{~mL})$ at $0^{\circ} \mathrm{C}$, di-tert-butyl-dicarbonate $(4.21 \mathrm{~g}$, $19.3 \mathrm{mmol}$ ) was added drop wise and allowed to stir at room temperature for $2 \mathrm{~h}$ while monitoring by TLC. After completion, the reaction mixture was diluted with $\mathrm{CH}_{2} \mathrm{Cl}_{2}(20 \mathrm{~mL})$ and washed with water $(2 \times 10 \mathrm{~mL})$. The organic layer was concentrated under vacuum to give tertbutyl 3-(methoxy(methyl)carbamoyl)-1 $H$-pyrazole-1-carboxylate ( $2.5 \mathrm{~g}, 76 \%$ yield), which was used without further purification in the next step; ${ }^{1} \mathrm{H} \mathrm{NMR}\left(400 \mathrm{MHz}, \mathrm{CDCl}_{3}\right): \delta 1.65(\mathrm{~s}, 9 \mathrm{H})$, 3.39 (brs, $3 \mathrm{H}), 3.81(\mathrm{~s}, 3 \mathrm{H}), 6.82(\mathrm{~d}, J=1.2 \mathrm{~Hz}, 1 \mathrm{H}), 8.08(\mathrm{~d}, J=1.2 \mathrm{~Hz}, 1 \mathrm{H})$.

(iv) To a solution of tert-butyl 3-(methoxy(methyl)carbamoyl)- $1 H$-pyrazole-1-carboxylate $(2.5 \mathrm{~g}, 9.8 \mathrm{mmol})$ in dry THF $(15 \mathrm{~mL})$ at $-78^{\circ} \mathrm{C}$ under $\mathrm{N}_{2}$ atmosphere, methyl magnesium bromide (50 mL, 3M solution) was added drop wise and stirred at that temperature for $2 \mathrm{~h}$. Then allowed the reaction to reach room temperature and continued stirring for $16 \mathrm{~h}$. After TLC showed completion, the reaction was quenched with saturated ammonium chloride solution $(25 \mathrm{~mL})$ and extracted with EtOAc $(3 \times 100 \mathrm{~mL})$. The combined organic layer was dried over anhydrous $\mathrm{Na}_{2} \mathrm{SO}_{4}$ and concentrated under reduced pressure to obtain 1-(1H-pyrazol-3-yl) 
ethan-1-one (1.0 g, 92\% yield), as a semisolid; ${ }^{1} \mathrm{H}$ NMR (400 MHz, $\left.\mathrm{CDCl}_{3}\right): \delta 8.20$ (brs, $\left.1 \mathrm{H}\right)$, $7.64(\mathrm{~d}, J=1.6 \mathrm{~Hz}, 1 \mathrm{H}), 6.85(\mathrm{~d}, J=1.2 \mathrm{~Hz}, 1 \mathrm{H}), 2.59(\mathrm{~s}, 3 \mathrm{H})$.

(v) To a solution of 1-(1H-pyrazol-3-yl)ethan-1-one $(0.80 \mathrm{~g}, 7.2 \mathrm{mmol})$ in $\mathrm{AcOH}(15 \mathrm{~mL})$, pyridinium bromide perbromide $(4.1 \mathrm{~g}, 14.5 \mathrm{mmol})$ was added and allowed the mixture to stir at room temperature for 24 hours. After TLC showed completion, diluted the mixture with EtOAc $(30 \mathrm{~mL})$ and washed with water $(3 \times 20 \mathrm{~mL})$. The organic layer was dried over $\mathrm{Na}_{2} \mathrm{SO}_{4}$ and concentrated to obtain 2-bromo-1-(1H-pyrazol-3-yl)ethan-1-one (1.0 g, 72\% yield), as a solid which was used in next step without further purification.

(vi) To a solution of 1-(pyridin-2-yl)thiourea $(0.242 \mathrm{~g}, 1.58 \mathrm{mmol})$ in DMF $(10 \mathrm{~mL})$, 2-bromo-1-(1H-pyrazol-3-yl)ethan-1-one $(0.30 \mathrm{~g}, 1.58 \mathrm{mmol})$ and triethylamine $(0.44 \mathrm{~mL}$, $3.16 \mathrm{mmol}$ ) were added successively and heated the mixture at $70^{\circ} \mathrm{C}$ for 2 hours. After TLC showed completion, reaction mixture was diluted with EtOAc $(30 \mathrm{~mL})$ and washed with water $(3 \times 10 \mathrm{~mL})$. The organic layer was dried over $\mathrm{Na}_{2} \mathrm{SO}_{4}$ and concentrated. The resulting residue was purified by column chromatography (silicagel, 100-200\#) and the desired product was eluted with $60 \%$ EtOAc in hexane. Concentration of the pure fractions afforded $\mathbf{5 9}(100 \mathrm{mg}$, $23 \%$ yield), as an off-white solid; ${ }^{1} \mathrm{H}$ NMR: $\left(300 \mathrm{MHz}, \mathrm{CD}_{3} \mathrm{OD}\right): \delta 6.67-6.68(\mathrm{~m}, 1 \mathrm{H}), 6.91-$ $6.95(\mathrm{~m}, 1 \mathrm{H}), 7.00(\mathrm{~d}, J=8.3 \mathrm{~Hz}, 1 \mathrm{H}), 7.16(\mathrm{~s}, 1 \mathrm{H}), 7.63(\mathrm{~s}, 1 \mathrm{H}), 7.55-7.71(\mathrm{~m}, 1 \mathrm{H}), 8.31-8.33$ (m, $1 \mathrm{H}) ; \mathrm{LCMS} \mathrm{m} / \mathrm{z}(\mathrm{M}+\mathrm{H}) 244.05$, purity: $94.6 \%$; HRMS MS ESI $m / z$ calcd for $\mathrm{C}_{11} \mathrm{H}_{9} \mathrm{~N}_{5} \mathrm{~S}(\mathrm{M}$ $+\mathrm{H})^{+} 244.0651$, found $244.0631(\Delta 2.0 \mathrm{ppm})$.

$\mathrm{N}$-(Pyridin-2-yl)-4-(quinolin-2-yl)thiazol-2-amine (60). To a solution of 1-(pyridin2-yl)thiourea (0.122 g, $0.7 \mathrm{mmol}$ ) in DMF (7 mL), 2-bromo-1-(quinolin-2-yl)ethan-1-one $(0.20 \mathrm{~g}, 0.7 \mathrm{mmol})$ and triethylamine $(0.33 \mathrm{~mL}, 2.3 \mathrm{mmol})$ were added successively and heated the mixture at $70^{\circ} \mathrm{C}$ for 2 hours. After TLC showed completion, the reaction mixture was diluted with EtOAc $(20 \mathrm{~mL})$ and washed with water $(3 \times 10 \mathrm{~mL})$. The organic layer was dried over $\mathrm{Na}_{2} \mathrm{SO}_{4}$ and concentrated. The resulting residue was purified by column chromatography (silicagel, 100-200\#) and the desired product was eluted with $0.5 \% \mathrm{CH}_{3} \mathrm{OH}$ in $\mathrm{CH}_{2} \mathrm{Cl}_{2}$. Concentration of the pure fractions afforded $\mathbf{6 0}\left(45 \mathrm{mg}, 18 \%\right.$ yield) as a green solid; ${ }^{1} \mathrm{H}$ NMR: (400 MHz, DMSO-d $\left.\mathrm{d}_{6}\right): \delta 6.95(\mathrm{t}, J=5.6 \mathrm{~Hz}, 1 \mathrm{H}), 7.12(\mathrm{~d}, J=8.4 \mathrm{~Hz}, 1 \mathrm{H}), 7.58(\mathrm{t}, J=7.6 \mathrm{~Hz}, 1 \mathrm{H})$, 7.72-7.78 (m, 2H), $7.88(\mathrm{~s}, 1 \mathrm{H}), 7.96-8.01(\mathrm{~m}, 2 \mathrm{H}), 8.18(\mathrm{~d}, J=8.8 \mathrm{~Hz}, 1 \mathrm{H}), 8.34(\mathrm{~d}, J=4 \mathrm{~Hz}$, $1 \mathrm{H}), 8.44(\mathrm{~d}, J=8.4 \mathrm{~Hz}, 1 \mathrm{H}), 11.54(\mathrm{~s}, 1 \mathrm{H}) ;{ }^{13} \mathrm{C}$ NMR: $\left(300 \mathrm{MHz}, \mathrm{DMSO}-\mathrm{d}_{6}\right): \delta 111.3,111.5$, $111.6,111.9,126.6,127.5,128.3,129.2,130.3,137.3,137.4,138.4,138.5,146.9,148.0,149.5$, $152.2,152.9,160.2 ;$ LCMS m/z $(\mathrm{M}+\mathrm{H}) 305.15$, purity $98.4 \%$; HRMS MS ESI $\mathrm{m} / z$ calcd for $\mathrm{C}_{17} \mathrm{H}_{12} \mathrm{~N}_{4} \mathrm{~S}(\mathrm{M}+\mathrm{H})^{+} 305.0816$, found $305.0838(\Delta 2.2 \mathrm{ppm})$.

$\mathrm{N}$-(Pyridin-2-yl)-4-(pyrimidin-4-yl)thiazol-2-amine (61). To a solution of 1-(pyridin2-yl)thiourea (0.182 g, $1.19 \mathrm{mmol}$ ) in DMF (5 mL), 2-bromo-1-(pyrimidin-4-yl)ethan-1-one $(0.20 \mathrm{~g}, 0.99 \mathrm{mmol})$ and triethylamine $(0.7 \mathrm{~mL}, 5.0 \mathrm{mmol})$ were added successively and heated the mixture at $70^{\circ} \mathrm{C}$ for 5 hours. After TLC showed completion, the reaction mixture was diluted with EtOAc $(20 \mathrm{~mL})$ and washed with water $(3 \times 10 \mathrm{~mL})$. The organic layer was dried over $\mathrm{Na}_{2} \mathrm{SO}_{4}$ and concentrated. The resulting residue was purified by flash column chromatography and the desired product was eluted with $5.5 \% \mathrm{CH}_{3} \mathrm{OH}$ in $\mathrm{CH}_{2} \mathrm{Cl}_{2}$. Concentration of the pure fractions afforded 61 (35 mg, 13\% yield), as a brown solid; ${ }^{1} \mathrm{H}$ NMR: $(400 \mathrm{MHz}$, DMSO$\left.\mathrm{d}_{6}\right): \delta 6.95-6.98(\mathrm{~m}, 1 \mathrm{H}), 7.11(\mathrm{~d}, J=8.4 \mathrm{~Hz}, 1 \mathrm{H}), 7.76-7.71(\mathrm{~m}, 1 \mathrm{H}), 7.90-7.93(\mathrm{~m}, 1 \mathrm{H}), 7.96$ $(\mathrm{s}, 1 \mathrm{H}), 8.33(\mathrm{~d}, J=4 \mathrm{~Hz}, 1 \mathrm{H}), 8.87(\mathrm{~d}, J=4.2 \mathrm{~Hz}, 1 \mathrm{H}), 9.16(\mathrm{~s}, 1 \mathrm{H}), 11.54(\mathrm{~s}, 1 \mathrm{H}) ;{ }^{13} \mathrm{C}$ NMR: (300 MHz, DMSO- $\mathrm{d}_{6}$ ): $\delta 111.3,114.5,116.8,117.0,138.6,146.8,147.2,152.0,158.8,158.9$, $159.0,160.7 ;$ LCMS m/z (M+H) 256.04, purity 95.0\%; HRMS MS ESI $m / z$ calcd for $\mathrm{C}_{12} \mathrm{H}_{9} \mathrm{~N}_{5} \mathrm{~S}$ $(\mathrm{M}+\mathrm{H})^{+} 256.0651$, found $256.0625(\Delta 2.6 \mathrm{ppm})$.

1- [2-(Pyridin-2-yl)-thiazol-4-yl]ethan-1-one (62). (i) To a solution of 2-(pyridin-2-yl) thiazole-4-carboxylic acid $(250 \mathrm{mg}, 1.21 \mathrm{mmol})$ and $\mathrm{N}, \mathrm{O}$-dimethylhydroxylamine hydrochloride (178 mg, $1.82 \mathrm{mmol})$ in $\mathrm{CH}_{2} \mathrm{Cl}_{2}(10 \mathrm{~mL})$, EDCI. $\mathrm{HCl}$ ( $\left.341 \mathrm{mg}, 1.82 \mathrm{mmol}\right), \mathrm{HOBt}$ (245 mg, 
$1.82 \mathrm{mmol}$ ) and DIPEA (0.55 mL, $3.02 \mathrm{mmol})$ were sequentially added and stirred at room temperature for $16 \mathrm{~h}$. After completion, the reaction was diluted with water $(10 \mathrm{~mL})$ and extracted with $\mathrm{CH}_{2} \mathrm{Cl}_{2}(2 \times 15 \mathrm{~mL})$. The combined organic layer was dried over $\mathrm{Na}_{2} \mathrm{SO}_{4}$ and concentrated under reduced pressure. The crude was further purified by column chromatography on silica gel (100-200 \#) using 30\% EtOAc in hexane as eluent to afford $N$-methoxy- $N$ methyl-2-(pyridin-2-yl)thiazole-4-carboxamide (130 mg, $43 \%$ yield), as an off-white solid; ${ }^{1} \mathrm{H}$ NMR ( $\left.400 \mathrm{MHz}, \mathrm{CDCl}_{3}\right): \delta 8.62(\mathrm{~d}, J=4.4 \mathrm{~Hz}, 1 \mathrm{H}), 8.23(\mathrm{~d}, J=8.0 \mathrm{~Hz}, 1 \mathrm{H}), 8.12(\mathrm{~s}, 1 \mathrm{H}), 7.81$ $(\mathrm{t}, J=7.6 \mathrm{~Hz}, 1 \mathrm{H}), 7.35(\mathrm{t}, J=7.6 \mathrm{~Hz}, 3 \mathrm{H}), 3.86(\mathrm{~s}, 3 \mathrm{H}), 3.48(\mathrm{~s}, 3 \mathrm{H})$.

(ii) To a solution of $\mathrm{N}$-methoxy- $\mathrm{N}$-methyl-2-(pyridin-2-yl)thiazole-4-carboxamide (50 mg, $0.2 \mathrm{mmol})$ in dry THF $(5 \mathrm{~mL})$ at $-78^{\circ} \mathrm{C}$ under $\mathrm{N}_{2}$ atmosphere, methyl magnesium bromide ( $3 \mathrm{M}$ solution, $1.0 \mathrm{~mL}$ ) was added drop wise and stirred at $-78^{\circ} \mathrm{C}$ for 4 hours. After TLC showed completion, quenched the reaction with saturated ammonium chloride solution $(5 \mathrm{~mL})$ and extracted with EtOAc $(3 \times 15 \mathrm{~mL})$. The combined organic layer was dried over anhydrous $\mathrm{Na}_{2} \mathrm{SO}_{4}$ and concentrated under reduced pressure. The crude was further purified by column chromatography on silica gel (100-200 \#) using 30\% EtOAc in hexane as eluent to obtain $\mathbf{6 2}$ (20 mg, $49 \%$ yield), as brown solid; ${ }^{1} \mathrm{H}$ NMR: $\left(300 \mathrm{MHz}, \mathrm{CD}_{3} \mathrm{OD}\right.$ ): $\delta 2.25(\mathrm{~s}, 3 \mathrm{H}), 7.32-7.36$ $(\mathrm{m}, 1 \mathrm{H}), 7.74(\mathrm{~s}, 1 \mathrm{H}), 7.86-7.91(\mathrm{~m}, 1 \mathrm{H}), 8.07(\mathrm{~d}, J=7.9 \mathrm{~Hz}, 1 \mathrm{H}), 8.55-8.56(\mathrm{~m}, 1 \mathrm{H}) ;{ }^{13} \mathrm{C}$ NMR: (300 MHz, $\left.\mathrm{CD}_{3} \mathrm{OD}\right): \delta 21.1,111.3,121.0,122.6,137.4,148.6$; LCMS m/z (M+H) 205.02, purity: 99.4\%; HRMS MS ESI $m / z$ calcd for $\mathrm{C}_{10} \mathrm{H}_{8} \mathrm{~N}_{2} \mathrm{OS}(\mathrm{M}+\mathrm{H})^{+} 205.043$, found $205.0425(\Delta$ $0.5 \mathrm{ppm})$.

$\mathrm{N}$-(4-Acetylthiazol-2-yl)adamantane-1-carboxamide (63). To a solution of 2-(adamantane-1-carboxamido)- $\mathrm{N}$-methoxy- $\mathrm{N}$-methylthiazole-4-carboxamide $(250 \mathrm{mg}, 0.7 \mathrm{mmol})$ in dry THF $(10 \mathrm{~mL})$ at $-78^{\circ} \mathrm{C}$ under $\mathrm{N}_{2}$ atmosphere, methyl magnesium bromide (3 $\mathrm{M}$ solution, $1.05 \mathrm{mmol}$ ) was added drop wise and stirred at $-78^{\circ} \mathrm{C}$ for 2 hours. After TLC showed completion, quenched the reaction with saturated ammonium chloride solution $(10 \mathrm{~mL})$ and extracted with EtOAc ( $3 \times 25 \mathrm{~mL})$. The combined organic layer was dried over anhydrous $\mathrm{Na}_{2} \mathrm{SO}_{4}$ and concentrated under reduced pressure. The crude was further purified by column chromatography on silica gel (100-200 \#) using 10\% EtOAc in hexane as eluent to obtain $\mathbf{6 3}$ (60 mg, 28\% yield), as off-white solid; ${ }^{1} \mathrm{H}$ NMR: (300 MHz, $\left.\mathrm{CDCl}_{3}\right)$ : $\delta 1.74-1.85(\mathrm{~m}, 6 \mathrm{H}), 1.99(\mathrm{~s}, 6 \mathrm{H}), 2.45$ (s, 3H), 2.60 (s, 3H), 7.79 (s, 1H), 8.94 (br s, $1 \mathrm{H}) ;{ }^{13} \mathrm{C} \mathrm{NMR:}\left(300 \mathrm{MHz}, \mathrm{CDCl}_{3}\right.$ ): $\delta$ 27.1, 27.8, $36.2,38.8,121.4 ;$ LCMS $\mathrm{m} / \mathrm{z}(\mathrm{M}+\mathrm{H}) 305.15$, purity: $99.9 \%$. HRMS MS ESI $\mathrm{m} / \mathrm{z}$ calcd for $\mathrm{C}_{16} \mathrm{H}_{20} \mathrm{~N}_{2} \mathrm{O}_{2} \mathrm{~S}(\mathrm{M}+\mathrm{H})^{+}$305.1318, found $305.1305(\Delta 1.3 \mathrm{ppm})$.

\section{$\mathrm{N}$ - [5- [4-(1,1-Dimethylethyl)phenyl]-1,3,4-thiadiazol-2-yl]-2-pyridinecarboxamide}

(64). To 5-(2-pyridinyl)-1,3,4-thiadiazol-2-amine ( $18 \mathrm{mg}, 0.1 \mathrm{mmol})$ dissolved in ethanol (1 $\mathrm{mL}$ ) was added 4-(1,1-dimethylethyl)benzoyl chloride $(0.028 \mathrm{~mL}, 0.1 \mathrm{mmol})$. The mixture was stirred at room temperature and the reaction was monitored via LC/MS. As the reaction progressed, precipitate formed. After $1 \mathrm{~h}$, the precipitate was collected via vacuum filtration and washed with $\mathrm{H}_{2} \mathrm{O}$. The resulting solid was recrystallized from ethanol to give 64 (13 $\mathrm{mg}, 38 \%$ yield), as a white solid; ${ }^{1} \mathrm{H}$ NMR: $\left(300 \mathrm{MHz}, \mathrm{CDCl}_{3}\right): \delta 1.41(\mathrm{~s}, 9 \mathrm{H}), 7.37-7.41(\mathrm{~m}, 2 \mathrm{H}), 7.60(\mathrm{~d}$, $J=8.3 \mathrm{~Hz}, 2 \mathrm{H}), 7.80-7.85(\mathrm{~m}, 1 \mathrm{H}), 8.20-8.28(\mathrm{~m}, 3 \mathrm{H}), 8.69-8.71(\mathrm{~m}, 1 \mathrm{H}), 12.12(\mathrm{br} \mathrm{s}, 1 \mathrm{H}) ;{ }^{13} \mathrm{C}$ NMR: $\left(300 \mathrm{MHz}, \mathrm{CDCl}_{3}\right): \delta 31.1,35.2,45.5,73.0,74.8,100.8,104.1,108.0,120.2,124.8,125.8$, $128.5,136.7,149.8$; HRMS MS ESI $m / z$ calcd for $\mathrm{C}_{18} \mathrm{H}_{18} \mathrm{~N}_{4} \mathrm{OS}(\mathrm{M}+\mathrm{H})^{+} 339.1274$, found $339.1256(\Delta 1.8 \mathrm{ppm})$.

$\mathrm{N}$-(2,6-Dimethylphenyl)-5-(pyridin-2-yl)-1,3,4-thiadiazol-2-amine (65). To a solution of picolinohydrazide (500 mg, $3.65 \mathrm{mmol}$ ) in ethanol (10 mL), 2-isothiocyanato-1,3-dimethylbenzene ( $595 \mathrm{mg}, 3.65 \mathrm{mmol}$ ) was added and the mixture was refluxed for $15 \mathrm{~h}$. After TLC showed completion, distilled off the solvent and the residue was washed with diethyl ether to obtain N-(2,6-dimethylphenyl)-2-picolinoylhydrazine-1-carbothioamide as off-white solid (1.0 g, 91\%). MS m/z (M+H) 301.23 
A mixture of N-(2,6-dimethylphenyl)-2-picolinoylhydrazinecarbothioamide (200 mg, 0.66 $\mathrm{mmol}$ ) and conc. $\mathrm{H}_{2} \mathrm{SO}_{4}(1 \mathrm{~mL})$ was stirred at room temperature for $8 \mathrm{~h}$ while monitoring by TLC analysis $\left(\mathrm{CH}_{3} \mathrm{OH}: \mathrm{CH}_{2} \mathrm{Cl}_{2}=1: 19\right)$. The reaction mixture was poured into ice cooled water $(10 \mathrm{~mL})$ and extracted with EtOAc $(3 \times 20 \mathrm{~mL})$. The combined organic layer was dried over anhydrous $\mathrm{Na}_{2} \mathrm{SO}_{4}$ and concentrated under reduced pressure. The crude was further purified by column chromatography on silica gel (100-200 mesh) using $1 \% \mathrm{CH}_{3} \mathrm{OH}$ in $\mathrm{CH}_{2} \mathrm{Cl}_{2}$ as eluent to afford 65 (30 mg, 16\%), as a white solid; ${ }^{1} \mathrm{H}$ NMR: (400 MHz, DMSO- $\left.\mathrm{d}_{6}\right): \delta 2.22(\mathrm{~s}, 6 \mathrm{H})$, $7.17(\mathrm{~s}, 3 \mathrm{H}), 7.40-7.44(\mathrm{~m}, 1 \mathrm{H}), 7.90-7.94(\mathrm{~m}, 1 \mathrm{H}), 8.05(\mathrm{~d}, J=8 \mathrm{~Hz}, 1 \mathrm{H}), 8.54-8.55(\mathrm{~m}, 1 \mathrm{H})$, 9.67 (s, $1 \mathrm{H}) ;{ }^{13} \mathrm{C}$ NMR: $\left(300 \mathrm{MHz}, \mathrm{CDCl}_{3}\right): \delta 18.1,119.7,124.0,128.1,129.0,136.4,136.6$, 136.7, 138.3, 149.22, 149.29, 149.9, 173.4; LCMS m/z (M+H) 283.08, purity 99.4\%; HRMS MS ESI $m / z$ calcd for $\mathrm{C}_{15} \mathrm{H}_{14} \mathrm{~N}_{4} \mathrm{~S}(\mathrm{M}+\mathrm{H})^{+} 283.1012$, found $283.1005(\Delta 0.7 \mathrm{ppm})$.

$\mathrm{N}$-(2,6-Dimethylphenyl)-5-(pyridin-2-yl)-1,3,4-oxadiazol-2-amine (66). To a solution of picolinohydrazide (500 mg, $3.65 \mathrm{mmol}$ ) in ethanol $(10 \mathrm{~mL}), 2$-isothiocyanato-1,3-dimethylbenzene ( $595 \mathrm{mg}, 3.65 \mathrm{mmol}$ ) was added and the mixture was refluxed for $15 \mathrm{~h}$. After TLC showed completion, distilled off the solvent and the residue was washed with diethyl ether to obtain N-(2,6-dimethylphenyl)-2-picolinoylhydrazine-1-carbothioamide as off-white solid (1.0 g, 91\%). MS m/z (M+H) 301.23

A mixture of N-(2,6-dimethylphenyl)-2-picolinoylhydrazinecarbothioamide (200 mg, 0.66 $\mathrm{mmol})$ and $\mathrm{EDC} . \mathrm{HCl}(511 \mathrm{mg}, 2.66 \mathrm{mmol})$ in $\mathrm{CH}_{2} \mathrm{Cl}_{2}(10 \mathrm{~mL})$ was stirred at room temperature for $15 \mathrm{~h}$ while monitoring by TLC analysis $\left(\mathrm{CH}_{3} \mathrm{OH}: \mathrm{CH}_{2} \mathrm{Cl}_{2}=1: 19\right)$. The reaction mixture was poured into ice cooled water $(10 \mathrm{~mL})$ and extracted with $\mathrm{CH}_{2} \mathrm{Cl}_{2}(3 \times 20 \mathrm{~mL})$. The combined organic layer was dried over anhydrous $\mathrm{Na}_{2} \mathrm{SO}_{4}$ and concentrated under reduced pressure. The crude was further purified by column chromatography on silica gel (100-200 mesh) using 1\% $\mathrm{CH}_{3} \mathrm{OH}$ in $\mathrm{CH}_{2} \mathrm{Cl}_{2}$ as eluent to afford $\mathbf{6 6}$ (70 mg, 39\%), as a white solid; ${ }^{1} \mathrm{H}$ NMR: (400 MHz, DMSO-d $\left.\mathrm{d}_{6}\right): \delta 2.21(\mathrm{~s}, 6 \mathrm{H}), 7.14(\mathrm{~s}, 3 \mathrm{H}), 7.50-7.53(\mathrm{~m}, 1 \mathrm{H}), 7.94-8.02(\mathrm{~m}, 2 \mathrm{H}), 8.66(\mathrm{~d}, J=4.4$ $\mathrm{Hz}, 1 \mathrm{H}), 9.65$ (s, $1 \mathrm{H}) ;{ }^{13} \mathrm{C}$ NMR: $\left(300 \mathrm{MHz}, \mathrm{CDCl}_{3}\right): \delta 16.8,121.7,125.3,127.3,128.2,135.7$, 137.7, 149.5; LCMS m/z (M+H) 267.11, purity 99.1\%; HRMS MS ESI $m / z$ calcd for $\mathrm{C}_{15} \mathrm{H}_{14} \mathrm{~N}_{4} \mathrm{O}$ $(\mathrm{M}+\mathrm{H})^{+} 267.124$, found $267.1224(\Delta 1.6 \mathrm{ppm})$.

$\mathrm{N}$-(2,6-Dimethylphenyl)-6-(pyridin-2-yl)pyrimidin-4-amine(67). A mixture of 6-chloro-N-(2,6-dimethylphenyl)pyrimidin-4-amine 12 (200 mg, $0.85 \mathrm{mmol}$ ), 2-(1,1,1-tributylstannyl)pyridine $(631 \mathrm{mg}, 1.7 \mathrm{mmol})$ in dry DMF $(8 \mathrm{~mL})$ in a seal tube was degassed for 20 minutes and $\mathrm{Pd}\left(\mathrm{PPh}_{3}\right)_{4}(148 \mathrm{mg}, 0.12 \mathrm{mmol})$ was added. The contents in the sealed tube were heated at $100^{\circ} \mathrm{C}$ for 16 hours. After TLC showed completion, diluted with water $(15 \mathrm{~mL})$ and extracted with EtOAc $(3 \times 30 \mathrm{~mL})$. The organic layer was dried over $\mathrm{Na}_{2} \mathrm{SO}_{4}$ and concentrated. The resulting residue was purified by column chromatography followed by prep-HPLC to obtain 67 (50 mg, 21\% yield), as a white solid; ${ }^{1} \mathrm{H}$ NMR: (400 MHz, DMSO-d 6 ): $\delta 2.14(\mathrm{~s}, 6 \mathrm{H})$, 6.73-6.77 (br s, 1H), 7.11-7.22 (m, 3H), $7.50(\mathrm{~d}, J=16.4 \mathrm{~Hz}, 1 \mathrm{H}), 7.94(\mathrm{~s}, 1 \mathrm{H}), 8.33$ (d, $J=8$ $\mathrm{Hz}, 1 \mathrm{H}), 8.45-8.71$ (m, 2H), 9.09 (s, $1 \mathrm{H}) ;{ }^{13} \mathrm{C}$ NMR: $\left(300 \mathrm{MHz}, \mathrm{CDCl}_{3}\right): \delta 18.4,121.6,124.8$, 127.7, 128.7, 128.9, 136.6, 136.9, 149.2, 158.5; LCMS m/z (M+H) 277.17, purity: 99.5\%; HRMS MS ESI $m / z$ calcd for $\mathrm{C}_{17} \mathrm{H}_{16} \mathrm{~N}_{4}(\mathrm{M}+\mathrm{H})^{+} 277.1448$, found $277.1438(\Delta 1.0 \mathrm{ppm})$.

4-tert-Butyl- $\mathrm{N}$ - [4-(pyridin-2-yl)pyrimidin-2-yl]benzamide (68). To a stirred solution of $\mathrm{MsCl}(93 \mathrm{mg}, 0.81 \mathrm{mmol})$ in DMA $(4 \mathrm{~mL})$ at $0^{\circ} \mathrm{C}$, under $\mathrm{N}_{2}$ atmosphere, a solution of 4-(tertbutyl)benzoic acid (105 mg, $0.58 \mathrm{mmol})$ and 2,6-lutidine $(0.18 \mathrm{~mL}, 1.6 \mathrm{mmol})$ in DMA $(2 \mathrm{~mL})$ was added and stirred for 15 minutes. To this mixture was added a solution of 4-(pyridin-2-yl) pyrimidin-2-amine $(100 \mathrm{mg}, 0.58 \mathrm{mmol})$ in DMA $(2 \mathrm{~mL})$. The reaction mixture was heated at $50^{\circ} \mathrm{C}$ for 3 hours while monitoring by TLC. After completion, the reaction mixture was diluted with water $(15 \mathrm{~mL})$ and extracted with EtOAc $(3 \times 25 \mathrm{~mL})$. The organic layer was dried over $\mathrm{Na}_{2} \mathrm{SO}_{4}$ and concentrated. The resulting crude was purified by column chromatography on silica gel (100-200 mesh) using $1 \% \mathrm{CH}_{3} \mathrm{OH}$ in $\mathrm{CH}_{2} \mathrm{Cl}_{2}$ as eluent to obtain 68 (33 mg, $17 \%$ yield), 
as a brown solid; ${ }^{1} \mathrm{H}$ NMR: $\left(300 \mathrm{MHz}, \mathrm{CDCl}_{3}\right): \delta 1.39(\mathrm{~s}, 9 \mathrm{H}), 7.42-7.46(\mathrm{~m}, 1 \mathrm{H}), 7.54(\mathrm{~d}$, $J=8.3 \mathrm{~Hz}, 2 \mathrm{H}), 7.86-7.89(\mathrm{~m}, 1 \mathrm{H}), 7.92(\mathrm{~d}, J=8.4 \mathrm{~Hz}, 2 \mathrm{H}), 8.11(\mathrm{~d}, J=5.1 \mathrm{~Hz}, 1 \mathrm{H}), 8.51(\mathrm{~d}$, $J=7.9 \mathrm{~Hz}, 1 \mathrm{H}), 8.70(\mathrm{~s}, 1 \mathrm{H}), 8.74-8.76(\mathrm{~m}, 1 \mathrm{H}), 8.82(\mathrm{~d}, J=5.2 \mathrm{~Hz}, 1 \mathrm{H}) ;{ }^{13} \mathrm{C}$ NMR: $(300 \mathrm{MHz}$, $\left.\mathrm{CDCl}_{3}\right): \delta 31.1,112.9,122.1,125.6,125.8,127.3,137.2,148.5,149.5,159.6 ;$ LCMS m/z $(\mathrm{M}-\mathrm{H})$ 333.21, purity: 96.3\%; HRMS MS ESI $m / z$ calcd for $\mathrm{C}_{20} \mathrm{H}_{20} \mathrm{~N}_{4} \mathrm{O}(\mathrm{M}+\mathrm{H})^{+} 333.1671$, found $333.1685(\Delta 1.4 \mathrm{ppm})$.

$N$ - [1-(Pyridin-2-yl)-1H-pyrazol-3-yl]adamantane-1-carboxamide (69). To 1-(2-Pyridyl)-1H-pyrazole-3-amine (15, $32 \mathrm{mg}, 0.2 \mathrm{mmol})$ dissolved in $\mathrm{CH}_{2} \mathrm{Cl}_{2}(1 \mathrm{~mL})$ was added tricyclo [3.3.1.1 $1^{3,7}$ ]decane-1-carbonyl chloride ( $\left.48 \mathrm{mg}, 0.24 \mathrm{mmol}\right)$. Upon addition, precipitate formed. The mixture was stirred at room temperature and the reaction was monitored via $\mathrm{LC} /$ MS. After $1 \mathrm{~h}$, the reaction was diluted in $5 \% \mathrm{~K}_{2} \mathrm{CO}_{3}$ in water $(2 \mathrm{~mL})$. The aqueous layer was extracted with EtOAc $(3 \times 25 \mathrm{~mL})$. The organic layers were combined, dried over $\mathrm{Na}_{2} \mathrm{SO}_{4}$ and concentrated in vacuo. The resulting crude was purified via flash column chromatography to give 69 (41 mg, 64\% yield), as a white solid; ${ }^{1} \mathrm{H}$ NMR: $\left(300 \mathrm{MHz}, \mathrm{CDCl}_{3}\right): \delta 1.77-1.83(\mathrm{~m}, 6 \mathrm{H})$, $2.00(\mathrm{~s}, 6 \mathrm{H}), 2.12(\mathrm{~s}, 3 \mathrm{H}), 7.03(\mathrm{~s}, 1 \mathrm{H}), 7.16-7.18(\mathrm{~m}, 1 \mathrm{H}), 7.74-7.82(\mathrm{~m}, 2 \mathrm{H}), 8.09(\mathrm{~s}, 1 \mathrm{H})$, 8.40-8.41 (m, 1H), 8.44 (br s, $1 \mathrm{H}) ;{ }^{13} \mathrm{C}$ NMR: $\left(300 \mathrm{MHz}, \mathrm{CDCl}_{3}\right): \delta 28.0,36.4,39.1,100.6$, $111.4,120.9,127.8,138.6,148.1$; HRMS MS ESI $m / z$ calcd for $\mathrm{C}_{19} \mathrm{H}_{22} \mathrm{~N}_{4} \mathrm{O}(\mathrm{M}+\mathrm{H})^{+} 323.1827$, found $323.1853(\Delta 2.6 \mathrm{ppm})$.

3-Cyclopentyl-1- [1-(pyridin-2-yl)-1H-pyrazol-3-yl]urea (70). To 1-(2-Pyridyl)-1H-pyrazole-3-amine $(\mathbf{1 5}, 32 \mathrm{mg}, 0.2 \mathrm{mmol})$ dissolved in $\mathrm{CH}_{2} \mathrm{Cl}_{2}(1 \mathrm{~mL})$ was added cyclopentanecarbonyl chloride $(0.04 \mathrm{~mL}, 0.24 \mathrm{mmol})$. Upon addition, precipitate formed. The mixture was stirred at room temperature and the reaction was monitored via LC/MS. After $1 \mathrm{~h}$, the reaction was diluted in $5 \% \mathrm{~K}_{2} \mathrm{CO}_{3}$ in water $(2 \mathrm{~mL})$. The aqueous layer was extracted with EtOAc $(3 \times 25$ $\mathrm{mL}$ ). The organic layers were combined, dried over $\mathrm{Na}_{2} \mathrm{SO}_{4}$ and concentrated in vacuo. The resulting crude was purified via flash column chromatography to give $\mathbf{7 0}$ (35 $\mathrm{mg}, 36 \%$ yield), as a white solid; ${ }^{1} \mathrm{H}$ NMR: $\left(300 \mathrm{MHz}, \mathrm{CDCl}_{3}\right): \delta 1.60-1.80(\mathrm{~m}, 7 \mathrm{H}), 2.07-2.09(\mathrm{~m}, 2 \mathrm{H}), 4.25-4.31$ $(\mathrm{m}, 1 \mathrm{H}), 6.11(\mathrm{~s}, 1 \mathrm{H}), 7.12-7.16(\mathrm{~m}, 1 \mathrm{H}), 7.60(\mathrm{~d}, J=8.1 \mathrm{~Hz}, 1 \mathrm{H}), 7.78-7.83(\mathrm{t}, J=7.4 \mathrm{~Hz}, 1 \mathrm{H})$, 7.97 (br s, $1 \mathrm{H}$ ), 8.38-8.43 (m, 2H), 8.59 (s, $1 \mathrm{H})$; ${ }^{13} \mathrm{C} \mathrm{NMR:} \mathrm{(300} \mathrm{MHz,} \mathrm{CDCl}_{3}$ ): 23.5, 33.5, 51.9, 98.0, 110.8, 120.5, 127.8, 138.6, 148.1, 150.8, 151.2, 155.1; HRMS MS ESI $m / z$ calcd for $\mathrm{C}_{14} \mathrm{H}_{17} \mathrm{~N}_{5} \mathrm{O}(\mathrm{M}+\mathrm{H})^{+} 272.1467$, found $272.1493(\Delta 2.6 \mathrm{ppm})$.

\section{Acknowledgments}

This research was funded in part by Eli Lilly and Company in support of the mission of the Lilly TB Drug Discovery Initiative and in part by grant OPP1024038 from the Bill \& Melinda Gates Foundation.

\section{Author Contributions}

Conceived and designed the experiments: EAK YO JVE ESZ TM PAH JOO TP. Performed the experiments: EAK MAB YO JVE TA JB ESZ SD NK TM JOO TP. Analyzed the data: EAK JVE JB ESZ NK TM PAH JOO TP. Contributed reagents/materials/analysis tools: EAK MAB YO JVE TA JB ESZ SD NK TM. Wrote the paper: EAK JVE JB ESZ JOO TP.

\section{References}

1. World Health Organization Global tuberculosis report 2014.

2. Mitchison D, Davies $G$. The chemotherapy of tuberculosis: past, present and future. Int J Tuberc Lung Dis. 2012; 16(6):724-32. doi: 10.5588/ijtld.12.0083 PMID: 22613684

3. Pethe K, Sequeira PC, Agarwalla S, Rhee K, Kuhen K, Phong WY, et al. A chemical genetic screen in Mycobacterium tuberculosis identifies carbon-source-dependent growth inhibitors devoid of in vivo efficacy. Nat Commun. 2010; 1(5):1-8. 
4. Ballell L, Bates RH, Young RJ, Alvarez-Gomez D, Alvarez-Ruiz E, Barroso V, et al. Fueling opensource drug discovery: 177 small-molecule leads against tuberculosis. ChemMedChem. 2013; 8 (2):313-21. doi: 10.1002/cmdc.201200428 PMID: 23307663

5. Ananthan S, Faaleolea ER, Goldman RC, Hobrath JV, Kwong CD, Laughon BE, et al. High-throughput screening for inhibitors of Mycobacterium tuberculosis H37Rv. Tuberculosis (Edinb). 2009; 89(5):33453.

6. Luger P, Daneck K, Engel W, Trummlitz G, Wagner K. Structure and physicochemical properties of meloxicam, a new NSAID. Eur J Pharm Sci. 1996; 4(3):175-87.

7. Das J, Chen P, Norris D, Padmanabha R, Lin J, Moquin RV, et al. 2-Aminothiazole as a novel kinase inhibitor template. structure-activity relationship studies toward the discovery of $\mathrm{N}$-(2-Chloro-6-methylphenyl)-2-[[6-[4-(2-hydroxyethyl)-1- piperazinyl)]-2-methyl-4-pyrimidinyl]amino)]-1,3-thiazole-5-carboxamide (Dasatinib, BMS-354825) as a potent pan-src kinase inhibitor. J Med Chem. 2006; 49(23):681932. PMID: 17154512

8. Inamoto $\mathrm{Y}$, Chiba T, Kamimura T, Takaya T. FK 482, a new orally active cephalosporin synthesis and biological properties. J Antibiot (Tokyo). 1988; 41(6):828-30.

9. Prasada Rao KVV, Dandala R, Sivakumaran M, Rani A, Naidu A. Novel compounds for the synthesis of cefdinir. J Heterocycl Chem. 2007; 44(2):309-14.

10. Meissner A, Boshoff HI, Vasan M, Duckworth BP, Barry CE, 3rd., Aldrich CC. Structure-activity relationships of 2-aminothiazoles effective against Mycobacterium tuberculosis. Bioorg Med Chem. 2013; 21 (21):6385-97. doi: 10.1016/j.bmc.2013.08.048 PMID: 24075144

11. Mjambili F, Njoroge M, Naran K, De Kock C, Smith PJ, Mizrahi V, et al. Synthesis and biological evaluation of 2-aminothiazole derivatives as antimycobacterial and antiplasmodial agents. Bioorg Med Chem Lett. 2014; 24(2):560-4. doi: 10.1016/j.bmcl.2013.12.022 PMID: 24373723

12. Hantzsch A. Über die oxy-thiazole oder thiazolone. Ber dtsch Chem Ges A/B. 1927; 60(2537-2545).

13. Egan RS, Tadanier J, Garmaise DL, Gaunce AP. Intermediates in the Hantzsch thiazole synthesis. J Org Chem. 1968; 33(12):4422-6.

14. Taurins A, Blaga A. Synthesis of pyridyl-and quinolyl-substituted 2-aminothiazoles. J Heterocycl Chem. 1970; 7(5):1137-41.

15. Ollinger J, Bailey MA, Moraski GC, Casey A, Florio S, Alling T, et al. A dual read-out assay to evaluate the potency of compounds active against Mycobacterium tuberculosis. PLoS One. 2013; 8(4):e60531. doi: 10.1371/journal.pone.0060531 PMID: 23593234

16. Sirgel FA, Wiid IJ, van Helden PD. Measuring minimum inhibitory concentrations in mycobacteria. In: Parish T, Brown AC, editors. Mycobacteria Protocols. 465. Totowa, NJ: Humana Press; 2009. p. 17386.

17. Garcia RJL, Pedregal C, Rodriguez JH. Synthesis and conformational analysis of some oxisuran metabolites and their O-methyl derivatives. Tetrahedron. 1987; 43(19):4407-16.

18. Frigola J, Colombo A, Pares J, Martinez L, Sagarra R, Roser R. Synthesis, structure and inhibitory effects on cyclooxygenase, lipoxygenase, thromboxane synthetase and platelet aggregation of 3amino-4,5-dihydro-1H-pyrazole derivatives. Eur J Med Chem. 1989; 24(4):435-45.

19. Aicher B, Kelter A-R, Coulter TS, Taylor S, Davenport AJ, Hesterkamp T, et al., inventors; Evotec A.G., assignee. Preparation of piperazine(thio)carboxamides as inhibitors of hematopoietic prostaglandin D synthase. Germany 2010. 